\title{
Soluble $\beta$-Glucan Polysaccharide Binding to the Lectin Site of Neutrophil or Natural Killer Cell Complement Receptor Type 3 (CD11b/CD18) Generates a Primed State of the Receptor Capable of Mediating Cytotoxicity of iC3b-Opsonized Target Cells
}

\author{
Václav Větvička, Brian P. Thornton, and Gordon D. Ross \\ The Division of Experimental Immunology and Immunopathology, Department of Pathology, University of Louisville, Louisville, \\ Kentucky 40292
}

\begin{abstract}
When phagocyte CR3 binds to iC3b on bacteria or yeast, phagocytosis and degranulation are triggered because of simultaneous recognition of $\mathrm{iC} 3 \mathrm{~b}$ via a CD11b I-domain binding site and specific microbial polysaccharides via a lectin site located $\mathrm{COOH}$-terminal to the I-domain. By contrast, when phagocyte or natural killer (NK) cell CR3 adheres to iC3b on erythrocytes or tumor cells that lack CR3-binding membrane polysaccharides, neither lysis nor cytotoxicity are stimulated. This investigation showed that soluble CR3specific polysaccharides such as $\beta$-glucan induced a primed state of CR3 that could trigger killing of iC3b-target cells that were otherwise resistant to cytotoxicity. Anti-CR3 added before sugars prevented priming, whereas anti-CR3 added after sugars blocked primed CR3 attachment to iC3b-targets. Polysaccharide priming required tyrosine kinase(s) and a magnesium-dependent conformational change of the I-domain that exposed the CBRM1/5 activation epitope. Unlike LPS or cytokines, polysaccharides did not up-regulate neutrophil CR3 expression nor expose the mAb 24 reporter epitope representing the high affinity ICAM1-binding state. The current data apparently explain the mechanism of tumoricidal $\beta$-glucans used for immunotherapy. These polysaccharides function through binding to phagocyte or NK cell CR3, priming the receptor for cytotoxicity of neoplastic tissues that are frequently targeted with iC3b and sparing normal tissues that lack iC3b. ( $J$. Clin. Invest. 1996. 98:50-61.) Key words: immunotherapy • neoplasms • integrins $\bullet$ monoclonal antibodies $\bullet$ biological response modifiers
\end{abstract}

\section{Introduction}

Soluble fungal $\beta$-glucans such as lentinan and schizophyllan have been used for tumor immunotherapy in Japan for the last 16 yr (1-7). Employed in a manner analogous to BCG, these polysaccharides promote natural host defense mechanisms

\footnotetext{
Address correspondence to Dr. Václav Větvička, Division of Experimental Immunology and Immunopathology, Department of Pathology, University of Louisville, Louisville, KY 40292. Phone: 502-8525355; FAX: 502-852-1177; E-mail: v0vetv01@ulkyvm.louisville.edu

Received for publication 5 March 1996 and accepted in revised form 4 April 1996.
}

J. Clin. Invest.

(C) The American Society for Clinical Investigation, Inc.

0021-9738/96/07/50/12 \$2.00

Volume 98, Number 1, July 1996, 50-61 and the development of specific tumor immunity. Numerous investigations in animals and humans have failed to define their exact mechanism of action. $\beta$-glucans have been shown to activate neutrophils $(8,9)$, macrophages $(10,11)$, and natural killer $(\mathrm{NK})^{1}$ cells $(12-14)$ to express potent tumoricidal activity, and the existence of a specific membrane receptor for $\beta$-glucan to mediate these responses was proposed $10 \mathrm{yr}$ ago (15). With the identification of CR3 (Mac-1, CD11b/CD18, or $\alpha_{M} \beta_{2}$-integrin) as the leukocyte membrane receptor for $\beta$-glucans (16), it should now be possible to determine the cellular basis for their action and to design more rational approaches for their use in tumor immunotherapy.

CR3 has been investigated extensively to characterize its role as both an iC3b-receptor and an adhesion molecule (1720). CR3 is one of the most important phagocyte receptors for recognition of microbial pathogens and is responsible for mediating phagocytosis, degranulation, and respiratory bursts in response to iC3b-opsonized bacteria and yeast $(17,21)$. CR3 also forms transmembrane complexes with glycosylphosphatidylinositol-linked membrane glycoproteins such as FcyRIIIB (CD16), the urokinase-plasminogen activator receptor (uPAR or CD87), or the LPS receptor CD14, providing these surfacebound molecules with transmembrane signaling capability (22-27). Critical to both of these functions is a lectin site in CD11b $\left(\alpha_{M}\right)$ that apparently must be attached to a polysaccharide for stimulation of cytotoxic reactions. Neutrophil responses to iC3b-zymosan were first shown to require this carbohydrate-lectin interaction $(28,29)$. Later, neutrophil FcyRIIIB responses to $\mathrm{IgG}$-immune complexes were shown to involve this lectin site $(23,24,30,31)$. The CR3 lectin site was recently mapped to a region of $\mathrm{CD} 11 \mathrm{~b}$ located $\mathrm{COOH}$-terminal to the I-domain binding sites for ICAM-1, fibrinogen, and iC3b. The sugar specificity of CR3 includes some polysaccharides containing mannose or $\mathrm{N}$-acetyl-D-glucosamine in addition to glucose (16).

The mechanism of polysaccharide stimulation of CR3 by iC3b-opsonized microbial organisms has not been defined. Nevertheless, with iC3b-opsonized targets lacking the appropriate saccharides, CR3 does not trigger cytotoxicity. Virtually no detectable neutrophil or monocyte response is stimulated by iC3b-opsonized erythrocytes (EC3bi) or iC3b-tumor cells despite avid CR3-dependent adhesion that blankets the phagocyte with these potential target cells. Likewise, NK cells that bear abundant CR3 do not lyse CR3-bound EC3bi or iC3b-tumor cells (32-34). With monocytes and neutrophils, CR3 is capable of stimulating phagocytosis of EC3bi after

1. Abbreviations used in this paper: EC3bi, iC3b-opsonized erythrocytes; NK, natural killer; PKC, protein kinase C; PTK, protein tyrosine kinase; $\mathrm{SZP}$, soluble zymosan polysaccharide. 
treatment with PMA, suggesting a role for protein kinase $\mathrm{C}$ (PKC) and phosphorylation $(35,36)$. Although CR3-dependent phagocytosis of zymosan or $\beta$-glucan particles does not require PMA, a role for $\mathrm{PKC}$ and phosphorylation in these responses was suggested by the finding that phagocytosis of particulate $\beta$-glucan was both associated with phosphorylation of the CR3 $\beta$-subunit (CD18) and blocked by the PKC inhibitor staurosporine (37).

The current investigation found that CR3 activation involved two distinct steps. First, soluble polysaccharides that bound to CR3 were shown to induce a novel primed state of the receptor. Second, it was demonstrated that such primed CR3 could later be activated to mediate cytotoxicity of target cells bearing only iC3b and lacking CR3-binding polysaccharides. SZP, a 10-kD mannose-rich "soluble zymosan polysaccharide," as well as immunotherapeutic $\beta$-glucans such as lentinan, were shown to prime neutrophil and NK cell CR3 for lysis of EC3bi and cytotoxicity of iC3b-tumor cells that were otherwise resistant to killing. Polysaccharide priming of CR3 was shown to involve a magnesium- and tyrosine kinasedependent conformational change of the I-domain that exposed the CBRM1/5 activation epitope but not the mAb 24 reporter epitope representing the high affinity ICAM-1 binding state.

\section{Methods}

Cell lines. The human erythroblastic leukemia cell line K562 was obtained from the American Type Culture Collection (ATCC, Rockville, MD). The murine tumor cell line YAC-1 was provided by Dr. Julie Djeu of the Moffitt Cancer Research Center, Tampa, FL. Each were maintained in RPMI 1640 medium supplemented with $10 \%$ FCS, $2 \mathrm{mM}$ glutamine, and antibiotics.

Reagents. Reagents and manufacturers were as follows: Ficoll, Histopaque, RPMI 1640, FCS, PMA, FITC, Triton X-100, barley $\beta$-glucan, particulate yeast $\beta$-glucan, rC5a, trypsin, soybean trypsin inhibitor, zymosan, E-TOXATE, polymyxin B, and DNAse I (Sigma Chemical Co., St. Louis, MO); staurosporine and BSA (Boehringer Mannheim Biochemicals, Indianapolis, IN); LPS from Escherichia coli 055:B5, genistein and herbimycin A (Calbiochem Corp., San Diego, CA); rTNF $\alpha$, was a gift from Dr. Susanne Becker, CE-Environmental, Inc., Chapel Hill, NC; rIL-2 (Intergen Co., Purchase, NY); Percoll and Dextran T500 (Pharmacia LKB Biotechnology, Piscataway, NJ); $\mathrm{Na}_{2}\left[{ }^{51} \mathrm{Cr}\right] \mathrm{O}_{4}$ (Amersham Life Science, Arlington Heights, IL); sheep and chicken erythrocytes (Cleveland Scientific, Bath, $\mathrm{OH}$ ); nylon wool (Polysciences Inc., Warrington, PA); Hypaque M (Winthrop Pharmaceuticals, New York, NY); HBSS (Gibco Laboratories, Grand Island, NY). A soluble yeast $\beta$-glucan $(\sim 19.6 \mathrm{kD})(\mathrm{MP}$ $\beta$-glucan) was obtained from Molecular Probes, Eugene, OR; lentinan, a soluble $\left(\sim 10^{3} \mathrm{kD}\right)$ mushroom-derived $\beta$-glucan, was provided by the Developmental Therapeutics Program, Division of Cancer Treatment, Drug Synthesis and Chemistry Branch, National Cancer Institute, National Institutes of Health, Bethesda, MD. SZP, a soluble $10-\mathrm{kD}$ polysaccharide with high affinity for the lectin site of CR3 that consists of $\sim 95 \%$ mannose and $\sim 5 \%$ glucose, was isolated as previously described (16). Recombinant IL-12 was a gift from Dr. Stan Wolf, Genetics Institute, Boston, MA.

$m A b$. Hybridomas secreting anti-CR3 (CD11b) mAb were obtained from the following sources: M1/70 (38) and OKM1 (39) from the ATCC, MN-41 (40) from Drs. Allison Eddy and Alfred Michael of the University of Minnesota, anti-Mo1/44 from Dr. Robert Todd of the University of Michigan. Purified IgG M522 (41) was provided by Prof. Dr. Ernst-Peter Rieber, Institute for Immunology, Munich University, Germany. The murine IgG1-secreting MOPC-21 myeloma was obtained from the ATCC and used as a source of negative control IgG. Each mAb was isolated from ascites fluid by $50 \%$ ammonium sulfate precipitation followed by Mono-Q (Pharmacia) anion exchange chromatography (42). The HNK-1 hybridoma secreting IgM anti-CD56 mAb was obtained from the ATCC and used to generate ascites fluid from which IgM was isolated by Mono-Q anion exchange chromatography followed by Superose 6 (Pharmacia) molecular sieve chromatography. An IgG anti-CD56 mAb was obtained from Dr. Gerry Ritz of the Dana Farber Cancer Institute, Boston MA, and conjugated to biotin (43). Either the IgM anti-CD56 conjugated to FITC (44) or the biotinylated $\mathrm{IgG}$ anti-CD56 in combination with streptavidin-phycoerythrin (Tago Inc., Burlingame, CA) was used to monitor the purity of isolated NK cells in isolated large granular lymphocyte fractions by flow cytometry.

Neutrophils. Neutrophils were isolated with reagents and labware known to be virtually free of LPS. Blood from healthy volunteers was drawn into LPS-free sodium citrate anticoagulant. Granulocytes were obtained by centrifugation of the blood cells through sterile, LPS-free Histopaque. After removal of erythrocytes by hypotonic lysis with LPS-free water (BioWhittaker Inc., Walkersville, MD), the neutrophil fraction was washed three times with LPS-free RPMI 1640 medium (BioWhittaker) containing 10\% LPS-free FCS (Sigma) and maintained in an ice-bath until used. The level of LPS contamination was monitored with the Limulus lysate based E-TOXATE test and shown to be $<0.005 \mathrm{U} / \mathrm{ml}$.

NK cells. Large granular lymphocytes were isolated by standard methods (45). Briefly, mononuclear cells were isolated from citrated blood on a Histopaque gradient. After five washes in RPMI 1640 medium, the monocytes and some B cells were depleted by adherence to plastic Petri dishes $\left(45 \mathrm{~min}, 37^{\circ} \mathrm{C}\right)$ followed by passage through a nylon wool column. After three washes with RPMI 1640, the low density cells were isolated using a Percoll density gradient. The percentage of $\mathrm{CD}^{2} 6^{+} \mathrm{NK}$ cells in this low-density fraction was $\geq 80 \%$.

EC3bi. Sheep or chicken EC3b were generated as previously described (46) by activation of purified C3 (47), first with trypsin, and then with a nickel-stabilized C3-convertase formed with factors $\mathrm{B}$ and D. The C3 added during the C3-convertase step (200 $\mu \mathrm{g}$ per $10^{9}$ $\mathrm{EC} 3 \mathrm{~b}, \mathrm{Bb}$ ) generated $\sim 5 \times 10^{4}$ fixed C3b per EC3b. For generation of EC3bi (46), the EC3b were incubated for 30 minutes at $37^{\circ} \mathrm{C}$ with $80 \mu \mathrm{g}$ factor $\mathrm{H}$ and $16 \mu \mathrm{g}$ factor I per $\mathrm{ml}$ of EC3b suspended at $10^{9} / \mathrm{ml}$ in BDVEA buffer ( $1 \%$ BSA and $2.5 \%$ dextrose in $3.5 \mathrm{mM}$ veronal buffer, $\mathrm{pH} 7.2$, and $4.0 \mathrm{mS}$ at $22^{\circ} \mathrm{C}$, containing $20 \mathrm{mM}$ EDTA, and 10 $\mathrm{mM}$ sodium azide). The type and quantity of fixed $\mathrm{C} 3$ fragments on the EC3bi were determined by measuring the uptake of ${ }^{125}$ I-labeled mAbs specific for C3c, C3bi-neoantigen, C3d, and C3g (46). LPS was functionally depleted from EC3bi preparations by addition of $10 \mu \mathrm{g} /$ $\mathrm{ml}$ of polymyxin $\mathrm{B}$.

Preparation of $i C 3 b-Y A C-1$. iC3b-YAC-1 cells were generated with purified $\mathrm{C}$ components by a procedure analogous to that used for EC3bi. YAC-1 cultures $\left(\geq 5 \times 10^{8}\right.$ cells and viability $\left.\geq 95 \%\right)$ were pelleted $\left(200 \mathrm{~g}, 12 \mathrm{~min}, 25^{\circ} \mathrm{C}\right)$, washed once with $\mathrm{Ca}^{2+}$ and $\mathrm{Mg}^{2+}$-free HBSS warmed to $37^{\circ} \mathrm{C}$, and suspended in $25 \mathrm{ml}$ of HBSS. Mock-treated control YAC-1 cells were generated in parallel with iC3b-YAC-1 cells by substitution of BSA for purified C, using the same volume additions and incubation conditions. $\mathrm{C} 3 \mathrm{~b}_{\mathrm{T}}$-YAC-1 cells were prepared by adding $2 \mathrm{mg}$ of $\mathrm{C} 3(10 \mathrm{mg} / \mathrm{ml}, \geq 95 \%$ native $\mathrm{C} 3)$ and $20 \mu \mathrm{l}$ trypsin $\left(1 \mathrm{mg} / \mathrm{ml}\right.$ in PBS) to a pellet of $10^{8}$ YAC- 1 cells and incubating at $37^{\circ} \mathrm{C}$ for $1 \mathrm{~min}$. For the mock-treated control cells, $2 \mathrm{mg}$ of BSA was used instead of C3. After incubation, each tube was filled with RPMI 1640 containing $1 \%$ BSA, $250 \mu \mathrm{g} / \mathrm{ml}$ soybean trypsin inhibitor, and $50 \mu \mathrm{g} / \mathrm{ml}$ DNAase I (to prevent cell clumping). The tubes were mixed and incubated for $10 \mathrm{~min}$ at $37^{\circ} \mathrm{C}$ with occasional mixing to allow complete inactivation of trypsin. The cells were pelleted, washed once in HBSS containing $1 \%$ BSA and $0.15 \mathrm{mM} \mathrm{NiCl} 2$ (HBSS/Ni/BSA), warmed to $37^{\circ} \mathrm{C}$, and suspended in $3 \mathrm{ml}$ of HBSS/ $\mathrm{Ni} / \mathrm{BSA}$ at $37^{\circ} \mathrm{C}$. Six million cells were removed from each tube to quantify bound $\mathrm{C} 3$ fragments with ${ }^{125} \mathrm{I}$-labeled anti-C3c, anti-C3bi neoantigen, and anti-C3g mAb (46). These cells were placed in a $50-\mathrm{ml}$ conical tube, washed with $20 \mathrm{ml}$ of ice-cold BDVEA, and 


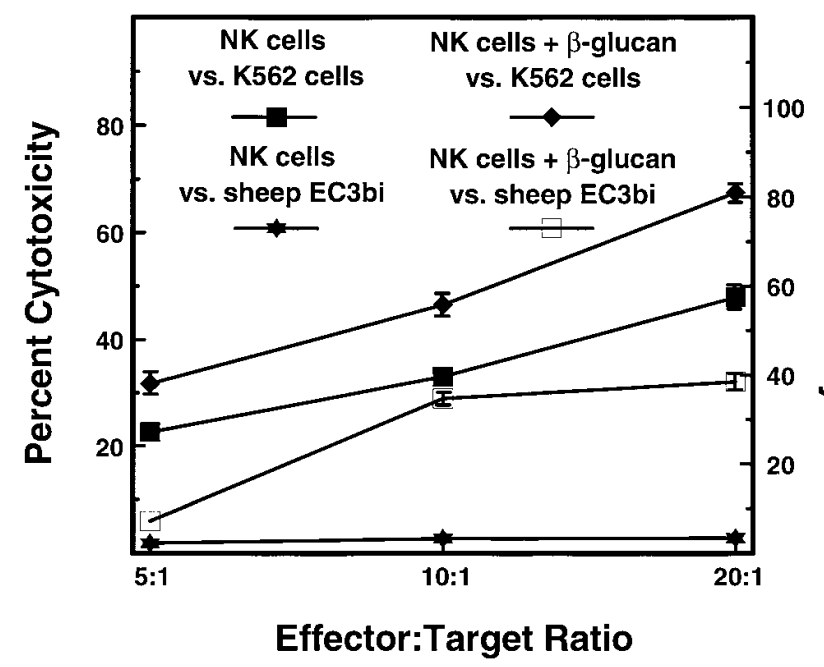

Figure 1. Soluble yeast MP $\beta$-glucan enhances NK cell cytotoxicity of K562 cells and induces NK cell hemolysis of sheep EC3bi. Different ratios of NK cells to K562 cells or EC3bi were tested for cytotoxicity or hemolysis in the presence or absence of $5.0 \mu \mathrm{g} / \mathrm{ml}$ of MP $\beta$-glucan after $4 \mathrm{~h}$ at $37^{\circ} \mathrm{C}$. The data points shown are mean values with SD error bars from three experiments; SD values $<1 \%$ are not shown. The enhancement of NK cell cytotoxicity of K562 cells was significant $(P<0.001)$ at all three effector to target cell ratios.

maintained as a cell pellet on ice until tested. To the remaining cells $\left(\sim 9 \times 10^{7}\right) 135 \mu \mathrm{g}$ of factor B was added. After $3 \mathrm{~min}$ at $37^{\circ} \mathrm{C}$ with gentle agitation, $348 \mathrm{ng}$ of factor $\mathrm{D}$ was added, and incubation was continued for $2 \mathrm{~min}$ at $37^{\circ} \mathrm{C}$ to form cell-bound C $3 \mathrm{~b}, \mathrm{Bb}$. Next, $300 \mu \mathrm{g}$ of C3 (or BSA for the mock-treated cell control) was added and incubation was continued at $37^{\circ} \mathrm{C}$ for $20 \mathrm{~min}$. Each tube was diluted to 50 $\mathrm{ml}$ with ice-cold $1 \% \mathrm{BSA} / \mathrm{RPMI}$, centrifuged as above, and the cells were washed twice with $1 \%$ BSA/RPMI. To generate iC3b-YAC-1 cells, the C3b-YAC-1 cells were resuspended in $4 \mathrm{ml}$ of $1 \% \mathrm{BSA} /$ RPMI, $320 \mu \mathrm{g}$ of factor $\mathrm{H}$ and $64 \mu \mathrm{g}$ of factor I were added, and incubation was continued for $15 \mathrm{~min}$ at $37^{\circ} \mathrm{C}$. The iC3b-YAC- 1 cells and mock-treated cells were washed twice and resuspended in $4 \mathrm{ml}$ of $1 \%$ BSA/RPMI. Approximately $6 \times 10^{6}$ cells were removed from each tube, washed twice in BDVEA, and saved for measurement of fixed $\mathrm{C} 3$ as above.

Labeling with ${ }^{51} \mathrm{Cr}$. Tumor cells or erythrocytes $\left(10^{8} / \mathrm{ml}\right.$ in RPMI 1640) were mixed with $100 \mu \mathrm{Ci}$ of ${ }^{51} \mathrm{Cr}$ for $60 \mathrm{~min}$ at $37^{\circ} \mathrm{C}$. After three washes, the labeled cells were resuspended at a concentration $10^{6} / \mathrm{ml}$ and used in cytotoxicity assays.

NK cell cytotoxicity assay. NK cells $\left(10^{6} / \mathrm{ml} ; 0.1 \mathrm{ml} /\right.$ well $)$ in $\mathrm{V}$-shaped 96-well microplates (Dynatech Laboratories Inc., Chantily, VI) were incubated with various activating or blocking agents for $30 \mathrm{~min}$ at $37^{\circ} \mathrm{C}$ and then washed three times with RPMI 1640 . The following concentrations of these agents were used: $1.0 \mu \mathrm{g} / \mathrm{ml}$ of $\mathrm{IgG} \mathrm{mAb}$ or myeloma IgG; $2 \mu \mathrm{g} / \mathrm{ml}$ of SZP; $5 \mu \mathrm{g} / \mathrm{ml}$ of MP $\beta$-glucan; $50 \mu \mathrm{g} / \mathrm{ml}$ of lentinan; $10 \mathrm{ng} / \mathrm{ml}$ PMA; $10 \mu \mathrm{g} / \mathrm{ml} \mathrm{LPS} ; 10 \mathrm{mM}$ rC5a; $5-100 \mathrm{U} / \mathrm{ml}$ of rIL-2; 5-20 U/ml of rIL-12; $10 \mathrm{ng} / \mathrm{ml}$ staurosporine; $20 \mu \mathrm{g} / \mathrm{ml}$ genistein; $3 \mu \mathrm{M}$ herbimycin A. After one wash with RPMI 1640, 200 $\mu \mathrm{l}$ of ${ }^{51} \mathrm{Cr}$-labeled target cells $\left(10^{5} / \mathrm{ml}\right.$ in RPMI 1640$)$ were added to each well and the plate was placed in an incubator at $37^{\circ} \mathrm{C}$ for $4 \mathrm{~h}$ in a humidified atmosphere with $5 \% \mathrm{CO}_{2}$. The plate was centrifuged to pellet effectors and target cells, and the radioactivity in $150 \mu \mathrm{l}$ of supernatant was measured using a Model 1261 Multigamma Counter (LKB Wallac Inc., Gaithersberg, MD).

Neutrophil cytotoxicity assay. Adherent neutrophil layers were generated in flat-bottom 96-well plates (Becton \& Dickinson Labware, Lincoln Park, NJ) by addition of $10^{5}$ cells per well in $1 \% \mathrm{BSA} /$ HBSS and incubation at $37^{\circ} \mathrm{C}$ for $45 \mathrm{~min}$. After three washes with

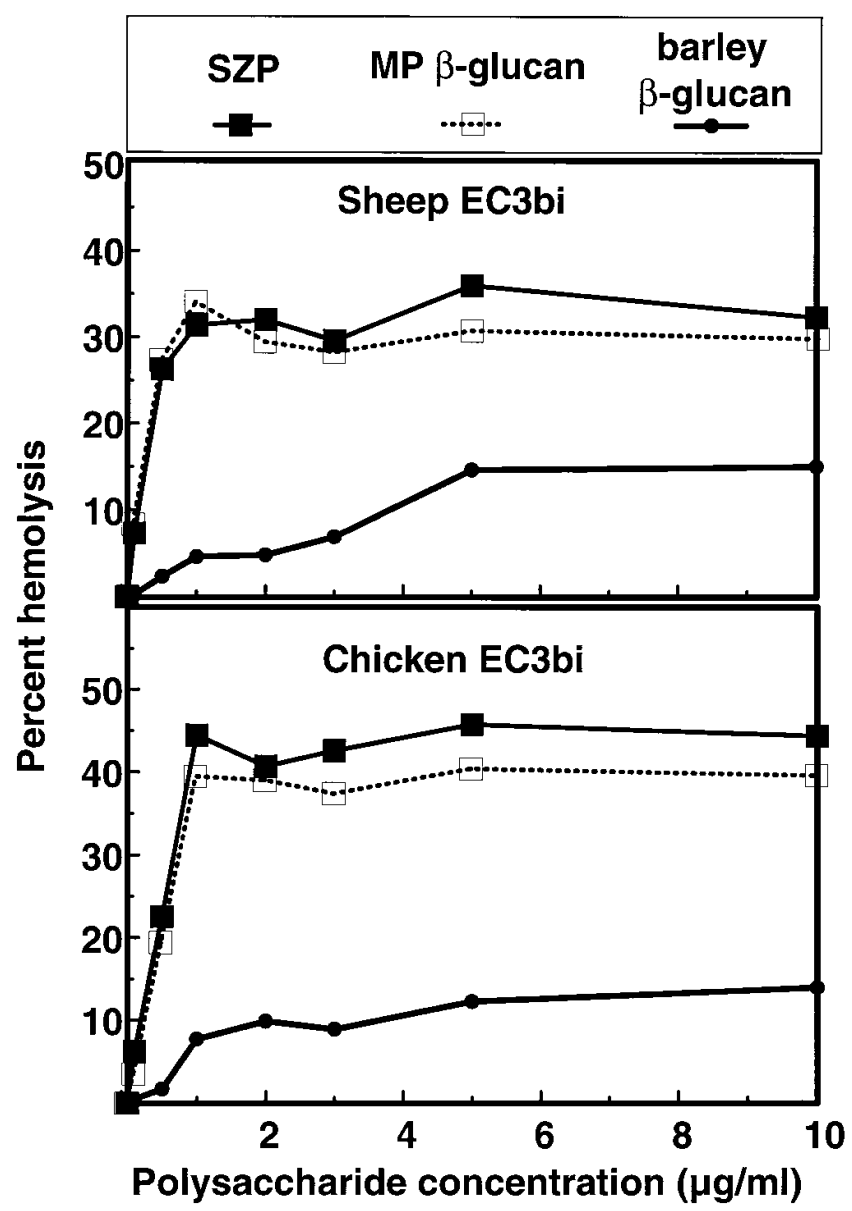

Figure 2. Dose-dependent induction of NK cell hemolysis of sheep or chicken EC3bi by SZP or $\beta$-glucans from yeast or barley. The results shown are from one of several representative titration assays in which each of these polysaccharides were tested on three or more batches of NK cells. Based on these results, $1.0-2.0 \mu \mathrm{g} / \mathrm{ml}$ of SZP or yeast MP $\beta$-glucan was used as the optimal priming dose in all subsequent experiments.

warm PBS, the adherent neutrophils were incubated with various activating or inhibiting agents (MP $\beta$-glucan, $\mathrm{mAb}$, etc.) for $30 \mathrm{~min}$ at $37^{\circ} \mathrm{C}$ before addition of ${ }^{51} \mathrm{Cr}$-labeled target cells as described above for NK cells. The same concentrations of agents were used as with NK cells except that with neutrophils only, rTNF $\alpha$ was also used as a test stimulating agent at $400 \mathrm{U} / \mathrm{ml}$, PMA was used at $50 \mathrm{ng} / \mathrm{ml}$, and LPS was used at $100 \mathrm{ng} / \mathrm{ml}$. rIL-2 and rIL-12 were only tested as CR3priming agents with NK cells.

Calculation of specific cytotoxicity. Percent specific ${ }^{51} \mathrm{Cr}$ release was calculated using the formula: percent specific ${ }^{51} \mathrm{Cr}$ release $=100$ $\times[$ cpm experimental $-\mathrm{cpm}$ spontaneous $) \div(\mathrm{cpm}$ maximum $-\mathrm{cpm}$ spontaneous)], where spontaneous release was that obtained from target cells incubated with medium alone and maximum release was that obtained by target cell lysis with $1 \%$ Triton X-100.

Assays for homotypic aggregation, superoxide burst, and enhanced adhesion. Neutrophils were tested with an aggregometer for homotypic aggregation (48). SZP $(0.1-1.0 \mathrm{mg} / \mathrm{ml})$ was compared to PMA $(0.1-1.0 \mu \mathrm{g} / \mathrm{ml})$ and fMLP $\left(10^{-7} \mathrm{M}\right)$ as positive controls. Tests for a neutrophil superoxide burst in response to particulate or soluble $\beta$-glucans were carried out using a spectrophotometric assay for reduction of ferricytochrome $\mathrm{C}(28,29)$. For analysis of enhanced adhesion and changes in morphology characteristic of activation, $250 \mu \mathrm{l}$ of neutrophils isolated under LPS-free conditions and suspended in 


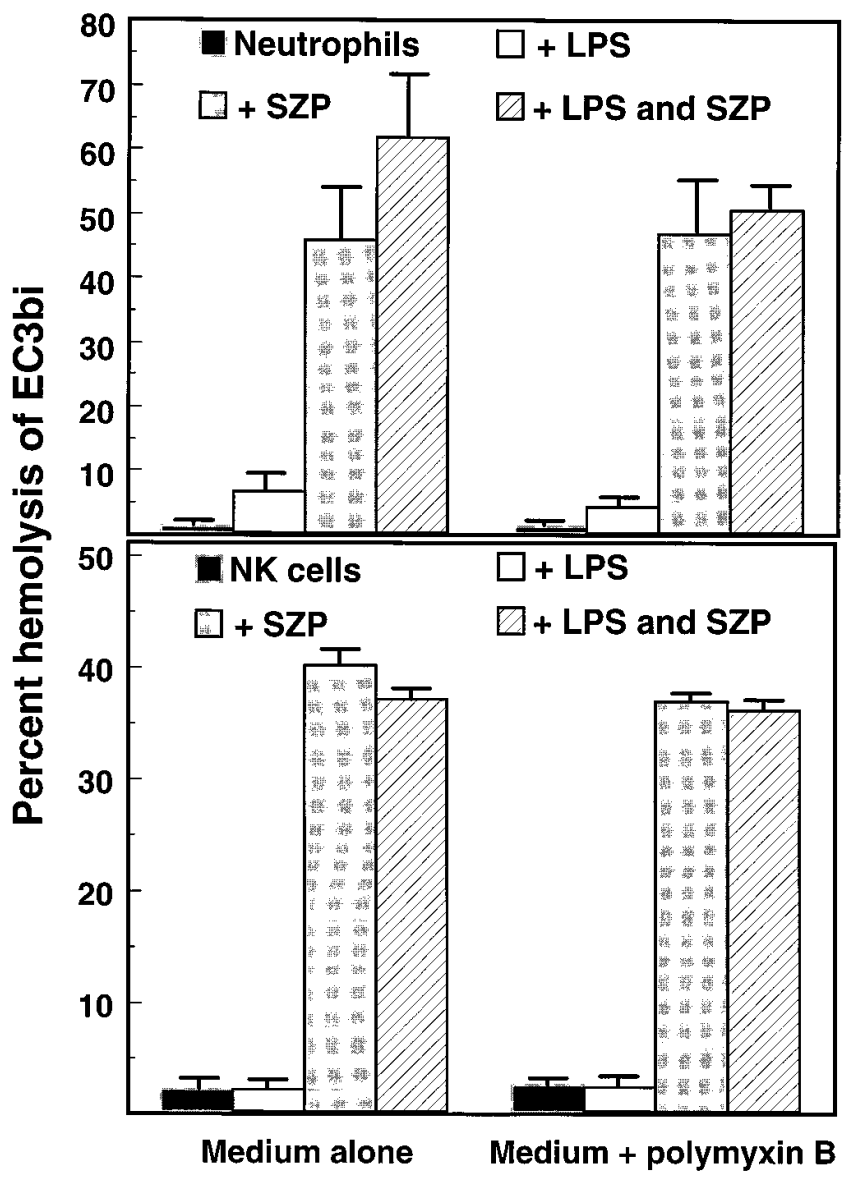

Figure 3. Priming of neutrophils or NK cells for lysis of sheep EC3bi by SZP versus LPS. Neutrophils or NK cells isolated under LPS-free conditions were examined for hemolysis of ${ }^{51} \mathrm{Cr}$-EC3bi using a 10:1 effector to target cell ratio and $4 \mathrm{~h}$ assay. Neutrophils and NK cells were induced to lyse EC3bi in medium containing $1.0 \mu \mathrm{g} / \mathrm{ml}$ of SZP but not in medium containing $100 \mathrm{ng} / \mathrm{ml}$ of LPS. There was a slight but significant enhancement of SZP-induced neutrophil hemolysis of EC3bi by LPS $(P<0.05)$, and this enhancement was blocked by the LPS inhibitor polymyxin $\mathrm{B}(P=0.054)$. The mean and SD from three experiments are shown.

RPMI $1640 /$ FCS at $2 \times 10^{6} / \mathrm{ml}$, were added to 24 -well culture plates and incubated at $37^{\circ} \mathrm{C}$ for $30 \mathrm{~min}$. After washing away unbound neutrophils with warm medium, the remaining adherent neutrophils were examined with an inverted phase-contrast microscope and $40 \times$ objective lens for cell density and morphology. Activating agents such as LPS $(100 \mathrm{ng} / \mathrm{ml})$, PMA $(20 \mathrm{ng} / \mathrm{ml})$, SZP $(2 \mu \mathrm{g} / \mathrm{ml})$, or MP $\beta$-glucan $(5 \mu \mathrm{g} / \mathrm{ml})$ were added to the culture wells before incubation at $37^{\circ} \mathrm{C}$.

Fluorescence staining technique and flow cytometry. Fluorescence staining and flow cytometry analysis was performed as described previously $(16,49)$.

Statistical evaluation of data. The Instat software package from Graph Pad (San Diego, CA) was used to perform statistical evaluations of data using the Student's $t$ test.

\section{Results}

CR3-binding soluble polysaccharides prime neutrophil and NK cell CR3 for extracellular cytotoxicity. As reported by Di Renzo et al. (13), NK cell cytotoxicity of K562 cells was enhanced by soluble $\beta$-glucan (Fig. 1), and this enhancement was blocked by OKM1 anti-CR3 (not shown). Anti-CR3 had no

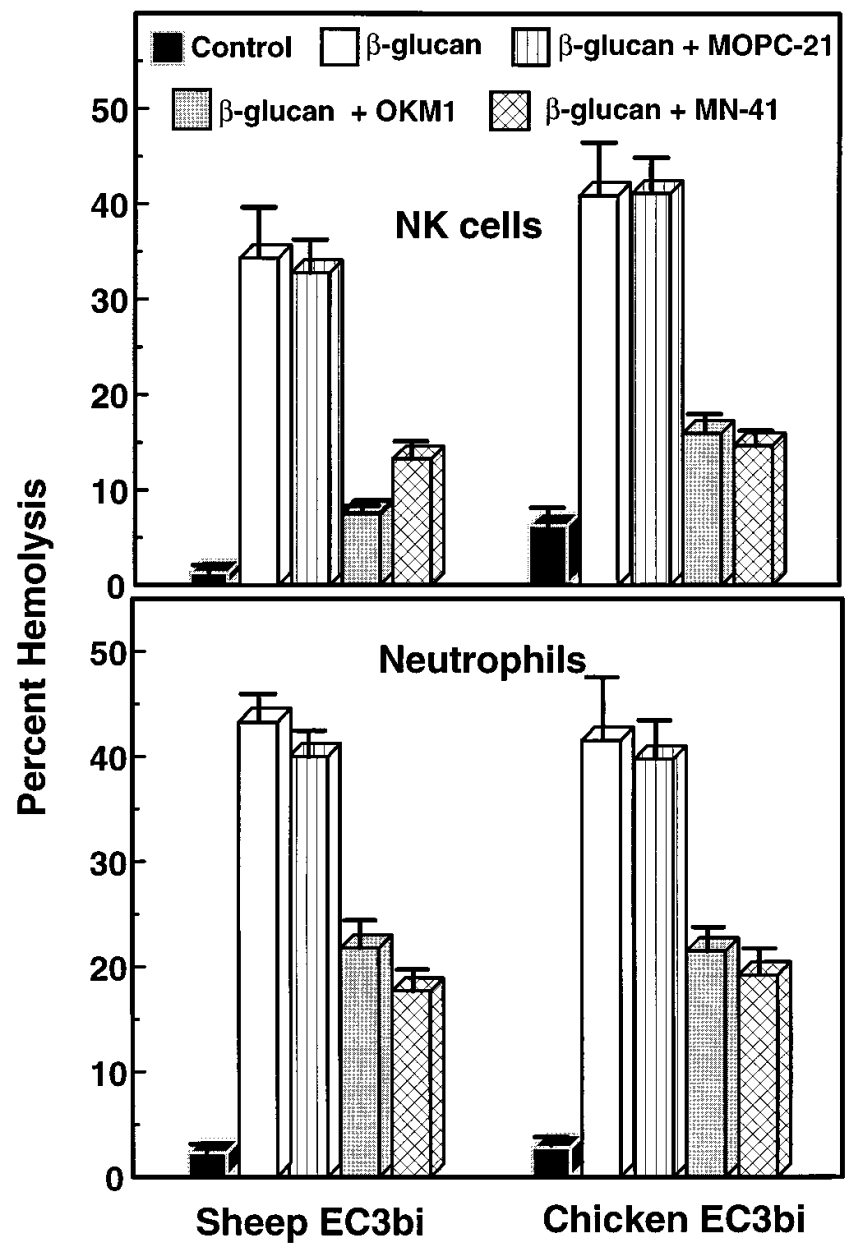

Figure 4. $\beta$-Glucan priming of CR3 for hemolysis of EC3bi is blocked by anti-CR3. The anti-CR3 mAbs OKM-1 or MN-41 inhibited NK cell or neutrophil hemolysis of sheep or chicken EC3bi induced by 2.0 $\mu \mathrm{g} / \mathrm{ml}$ of MP $\beta$-glucan. The results represent the mean and SD of three experiments in which anti-CR3 mAbs were added to NK cells or neutrophils $30 \mathrm{~min}$ before the $\beta$-glucan and ${ }^{51} \mathrm{Cr}$-labeled EC3bi. Similar results were obtained if the MP $\beta$-glucan was added to the NK cells or neutrophils 30 min before the ${ }^{51} \mathrm{Cr}$-EC3bi and anti-CR3 $\mathrm{mAb}$. SZP induced similar CR3-dependent hemolytic activity (not shown). MOPC-21 myeloma IgG did not inhibit hemolysis induced by $\beta$-glucan or SZP.

effect on normal mechanisms of NK cell cytotoxicity of K562 cells that have previously been shown to be CR3-independent (38). Unlike K562 cells, EC3bi are completely resistant to normal mechanisms of NK cell recognition and are not lysed despite avid attachment to NK cells via CR3 $(32,33)$. Addition of soluble $\beta$-glucans to NK cells stimulated hemolysis of sheep EC3bi, and nearly $40 \%$ hemolysis was achieved at an effector to target cell ratio of 20:1 (Fig. 1). Both sheep and nucleated chicken EC3bi were sensitive to hemolysis by NK cells treated with $\beta$-glucans (Fig. 2), but no hemolysis was stimulated with $\mathrm{E}$ lacking bound $\mathrm{iC} 3 \mathrm{~b}$. Barley $\beta$-glucan, that has a relatively low affinity for CR3 (16), induced a lower level of EC3bi hemolysis than did soluble yeast MP $\beta$-glucan or SZP (Fig. 2) that have a considerably higher affinity for CR3. Maximum hemolysis was induced by only $1-2 \mu \mathrm{g} / \mathrm{ml}$ of SZP or MP $\beta$-glucan, a concentration that had been shown previously to saturate membrane CR3 (16). 


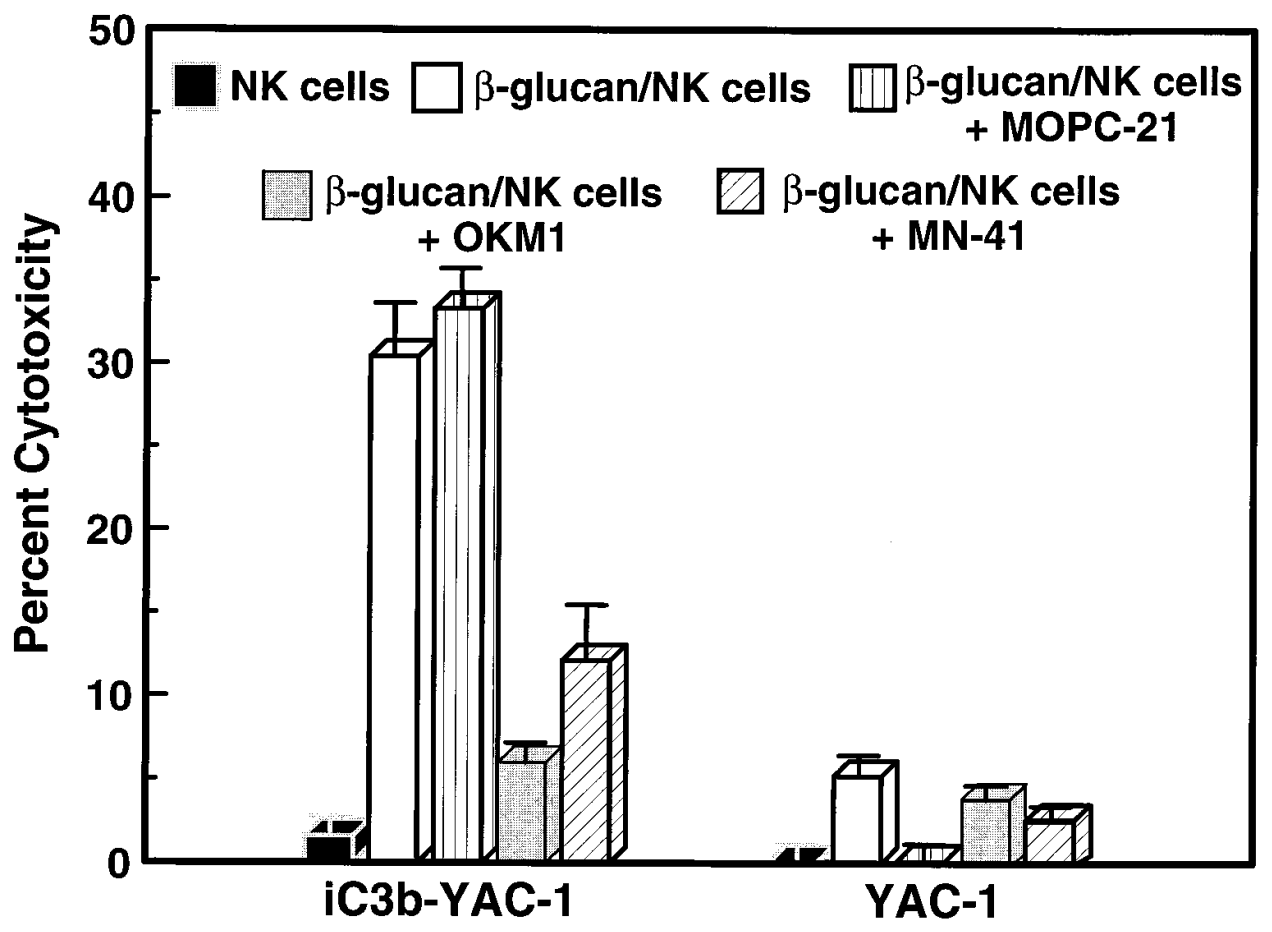

Figure 5. $\beta$-Glucan activation of NK cells to kill murine YAC-1 tumor cells bearing iC3b (iC3b-

YAC-1) but not YAC-1 cells lacking iC $3 b$. YAC-1 cells were coated with iC3b using purified human $\mathrm{C} 3$ and factors B, D, H, and I. Assays for uptake of ${ }^{125}$ I-anti-C3bi indicated that the iC $3 b-Y A C-1$ cells bore $\sim 4 \times 10^{5}$ molecules of iC $3 \mathrm{~b}$ per cell. The YAC-1 control cells were mock-treated with $\mathrm{C}$ components in parallel with the iC3bYAC-1 cells by substituting BSA for $\mathrm{C}$ components (see Methods for details). Lysis of iC3b-YAC-1 was inhibited by anti-CR3 but not by MOPC- 21 myeloma IgG. Similar results were obtained when anti-CR3 $\mathrm{mAbs}$ were added either before (shown) or after the MP $\beta$-glucan (not shown), or when SZP was used as the priming agent instead of MP $\beta$-glucan.

Neutrophils also failed to lyse EC3bi despite avid adhesion (Fig. 3). As with NK cells, $2 \mu \mathrm{g} / \mathrm{ml}$ of SZP (Fig. 3) or MP $\beta$-glucan (not shown) induced $\sim 50 \%$ neutrophil hemolysis of EC3bi. By contrast, $0.1-1.0 \mu \mathrm{g} / \mathrm{ml}$ of LPS induced little neutrophil hemolysis of EC3bi $(7.5 \pm 2.4 \%, P \leq 0.01)$. LPS did exhibit a small but significant additive effect on neutrophil hemolysis of EC3bi when mixed with SZP that was blocked by polymyxin B. This potentiation by LPS may be due to the large increase in surface expression of CR3 induced by LPS but not by SZP (See Fig. 10). As expected, CD14-negative NK cells did not respond to LPS, with or without SZP (Fig. 3).

Polysaccharide-induced lysis is CR3-dependent. With both NK cells and neutrophils, SZP- or $\beta$-glucan-induced hemolysis of sheep or chicken EC3bi was inhibited by mAb to CR3, whereas myeloma IgG had no effect (Fig. 4). Moreover, hemolysis was inhibited when anti-CR3 was added either before the polysaccharide to prevent its attachment to the CR3 lectin site (16) or after the polysaccharide to prevent attachment of the polysaccharide-primed CR3 to the iC3b on target cells (not shown).

Similar findings were made with murine YAC-1 tumor cells opsonized with iC3b (Fig. 5). Unlike human K562 cells, murine YAC-1 cells are not recognized by human NK cells and are killed only by murine NK cells. Neither yeast MP $\beta$-glucan (Fig. 5) nor SZP (not shown) could induce human NK cells to kill biologically significant proportions of YAC-1 cells (3.5 \pm $1.7 \%$ cytotoxicity, $P \leq 0.01$ ). There was even less NK cell cytotoxicity of iC3b-YAC-1 bearing $\sim 4 \times 10^{5}$ molecules of iC $3 \mathrm{~b}$ per cell $(1.9 \pm 0.8 \% ; P>0.05)$, despite avid CR3-dependent rosette formation. This low level of NK cell killing of iC3bYAC-1 cells was enhanced more than 10 -fold by priming CR3 with either SZP or $\beta$-glucan $(31.8 \pm 3.2 \%, P<0.001)$, and this enhanced cytotoxicity was blocked by mAbs to CR3 but not by myeloma IgG (Fig. 5).

mAb 522 mimics polysaccharides and primes CR3 for cytotoxicity. Although other mAb to CD11b (MN-41, OKM1,
M1/70, and anti-Mo1/44) inhibited polysaccharide-induced CR3-dependent cytotoxicity of iC3b-opsonized target cells, the mAb M522 mimicked SZP and $\beta$-glucans and primed CR3 for cytotoxicity (Fig. 6). The NK cell lytic activity induced by M522 was CR3-dependent because it was inhibited by another $\mathrm{mAb}$ to CD11b, OKM1. Both M522 and OKM1 react with $\mathrm{COOH}$-terminal domain epitopes that are close to the lectin site (16), but OKM1 differs from M522 in that it blocks the attachment of primed CR3 to the iC3b of target cells. Cross-

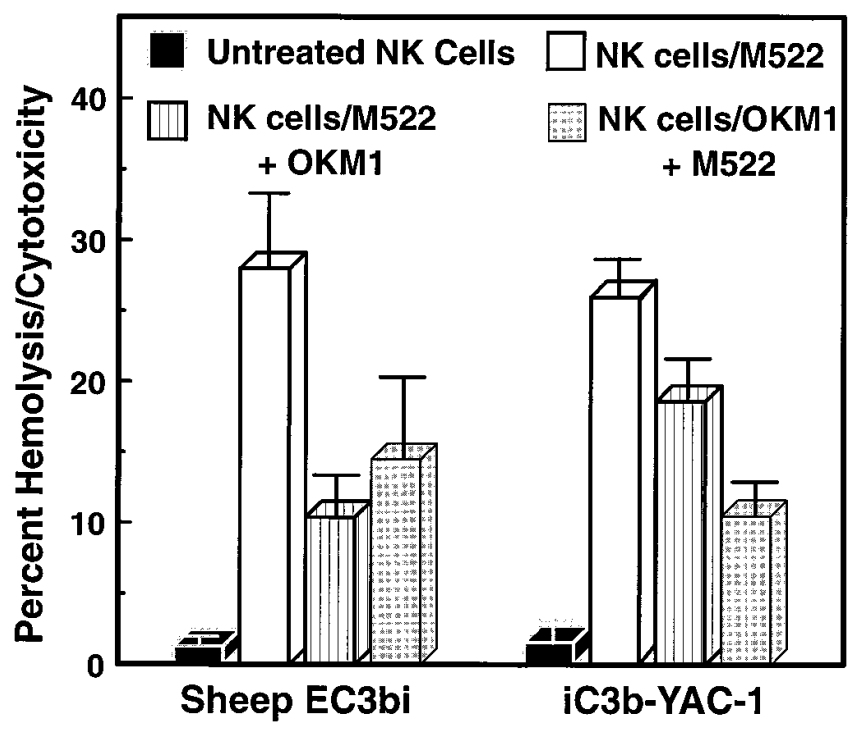

Figure 6. Priming of NK cells by M522 anti-CR3 mAb to lyse sheep EC3bi or kill iC3b-YAC-1 cells. The cytotoxic activity induced by M522 was inhibited partially by the addition of OKM1 anti-CR3 mAb either before (NK cells/OKM-1 + M522) or after (NK cells/ M522 + OKM1) the addition of M522. The mean and SD from three experiments are shown. 


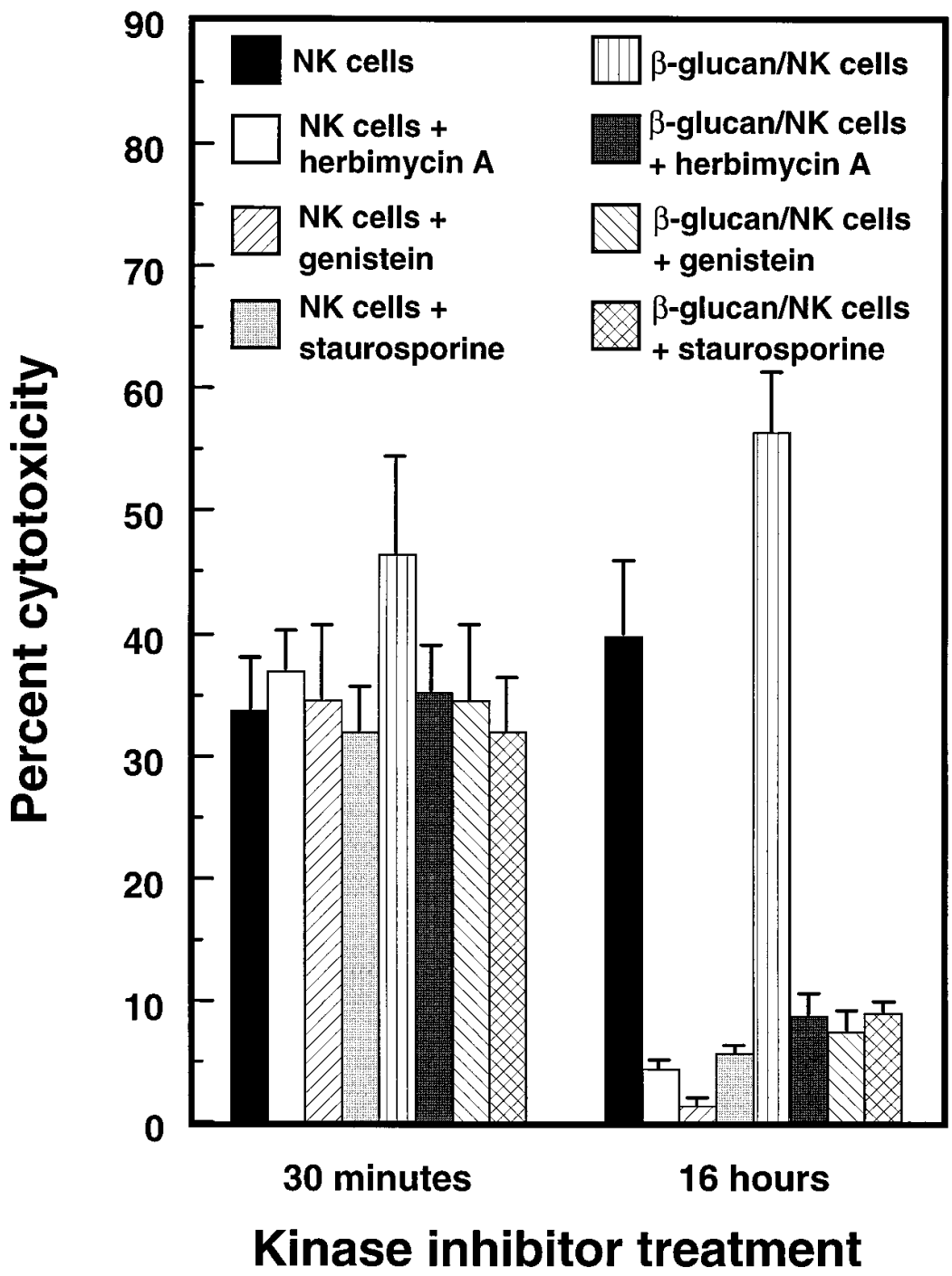

Figure 7. Inhibition of $\beta$-glucan-enhanced NK cell cytotoxicity of K562 cells by protein kinase inhibitors. Thirty minutes treatment of NK cells with staurosporine, herbimycin $\mathrm{A}$, or genistein selectively inhibited the CR3-dependent enhancement of NK cell cytotoxicity generated by treatment with MP $\beta$-glucan, but did not reduce endogenous levels of CR3-independent NK cell killing of K562 cells that occur without $\beta$-glucan stimulation. By contrast, a longer 16-h treatment of NK cells with these same protein kinase inhibitors was required to block endogenous mechanisms of CR3-independent NK cell cytotoxicity of K562 cells. The results given represent the mean and SD from three experiments. blocking studies also showed that the epitopes recognized by OKM1 and M522 are completely nonoverlapping in that OKM1 did not block neutrophil staining with M522-FITC, and conversely, unlabeled M522 did not block neutrophil staining with OKM1-FITC. Thus, OKM1 and M522 can bind to CR3 simultaneously, but the bound OKM1 can prevent attachment of the M522-primed CR3 to target cell bound iC3b.

Polysaccharide priming of CR3 is tyrosine kinase dependent. A brief 30-min treatment of NK cells with the PKC inhibitor staurosporine or the protein tyrosine kinase (PTK) inhibitors genistein or herbimycin A, selectively inhibited $\beta$-glucan priming of CR3 for enhanced cytotoxicity of K562 cells $(P<$ $0.05)$ without inhibiting baseline CR3-independent mechanisms of K562 cell cytotoxicity (Fig. 7). As shown previously by others (50), a $16 \mathrm{~h}$ treatment of NK cells with PTK inhibitors was required to block normal CR3-independent mechanisms of K562 cell cytotoxicity (Fig. 7).

This same 30-min treatment of NK cells or neutrophils with PKC or PTK inhibitors also blocked $\beta$-glucan- or SZP-induced hemolysis of sheep or chicken EC3bi (Fig. 8), as well as NK cell cytotoxicity of iC3b-YAC-1 cells (Fig. 9). Although staurosporine was known to induce both an upregulation of neutrophil CR3 surface expression and degranulation, neutrophil and NK cell viability were not reduced by any of these three kinase inhibitors, nor did the kinase inhibitors induce significant cytotoxic or hemolytic activity against target cells. Further evidence for a role of $\mathrm{PKC}$ in priming CR3 came from studies with PMA. Others have previously shown that PMA could prime neutrophil CR3 for phagocytosis of EC3bi (36) or cytotoxicity of K562 cells (51). This investigation found that PMA could also prime NK cell CR3 for hemolysis of EC3bi (not shown) or cytotoxicity iC3b-YAC-1 cells (Fig. 9). However, with the exception of PMA, all other neutrophil and NK cell activators that were examined $\left(10^{2}-10^{4} \mathrm{U}\right.$ of rIL-2, rIL-12, or rTNF $\alpha, 0.1-10 \mu \mathrm{g} / \mathrm{ml}$ of LPS, and $10^{-9}-10^{-7} \mathrm{M} \mathrm{rC5a}$ ) failed to prime CR3 for cytotoxicity iC3b-opsonized target cells in the same manner as did $\beta$-glucans or SZP.

Cell surface, morphologic, and proinflammatory characteristics of neutrophils and NK cells bearing polysaccharideprimed CR3. In contrast to neutrophils treated with LPS, $\mathrm{C} 5 \mathrm{a}$, or $\mathrm{TNF} \alpha$, neutrophils bearing polysaccharide-primed CR3 showed no signs of cellular activation. Cells remained small and round, there was no evidence for enhanced adhesion to culture surfaces, and no obvious degranulation (not shown). In addition, neither $0.1-1.0 \mathrm{mg} / \mathrm{ml}$ of SZP nor $5-50 \mu \mathrm{g} / \mathrm{ml}$ of mAb M522 induced neutrophil homotypic aggregation, and $100-500 \mu \mathrm{g} / \mathrm{ml}$ of SZP did not stimulate a superoxide burst. However, $250-500 \mu \mathrm{g} / \mathrm{ml}$ of lentinan, a high mol wt soluble 

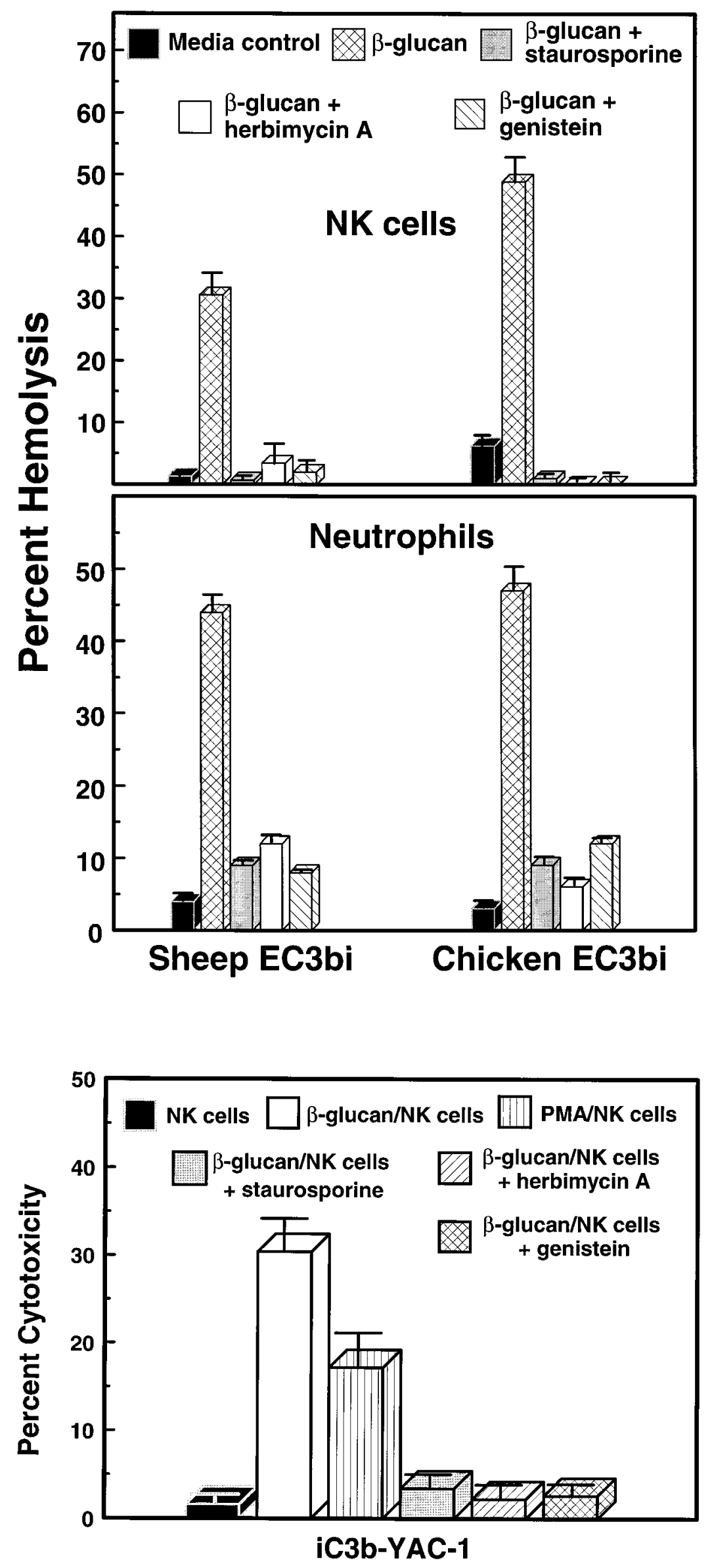

Figure 8. Inhibition of NK cell or neutrophil hemolysis of sheep or chicken EC3bi by protein kinase inhibitors. Hemolysis of the avidly bound EC3bi was not induced without priming of the NK cells or neutrophils with MP $\beta$-glucan (shown) or SZP (not shown), and the hemolysis induced by such polysaccharide priming was blocked by 30 -min treatment of the NK cells or neutrophils with staurosporine, herbimycin A, or genistein.
Figure 9. Inhibition of $\beta$-glucan-induced NK cell cytotoxicity of iC3b-YAC-1 cells by protein kinase inhibitors. PMA $(50 \mathrm{ng} / \mathrm{ml})$ induced NK cell cytotoxicity of iC3b-YAC-1 cells that was comparable to that induced by polysaccharide-priming of NK cells. Prior incubation of the NK cells for 30 min with PKC or PTK inhibitors prevented $\beta$-glucan-induced cytotoxicity. 


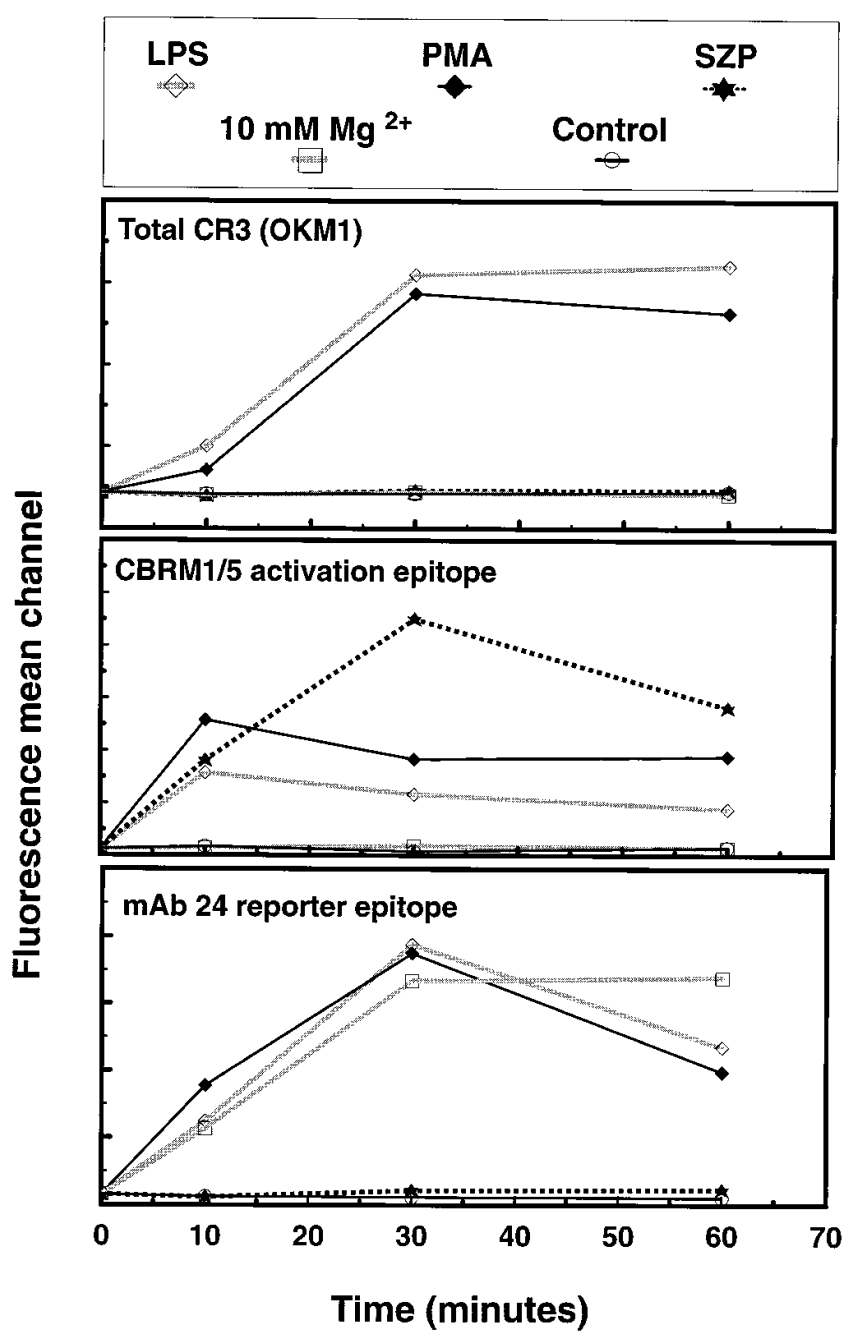

Figure 10. Up-regulation of neutrophil CR3 number and activation epitopes by stimulation with SZP versus LPS or PMA. Neutrophils isolated under LPS-free conditions were incubated at $37^{\circ} \mathrm{C}$ in RPMI/ FCS medium containing $50 \mathrm{ng} / \mathrm{ml}$ of PMA, $100 \mathrm{ng} / \mathrm{ml} \mathrm{LPS,} 2 \mu \mathrm{g} / \mathrm{ml}$ SZP (shown), or a mixture of LPS plus SZP (not shown). Medium containing $10 \mathrm{mM}$ magnesium chloride $\left(\mathrm{Mg}^{2+}\right)$ was used as a positive control to stimulate maximum expression of mAb 24 epitope. At the indicated time intervals, samples of the neutrophil suspension were washed into ice-cold medium and analyzed by flow cytometry. Total CR3 was assessed with OKM1-FITC. The results given represent the mean values from three experiments in which the three markers were tested simultaneously with the same neutrophil isolate.

$\beta$-glucan that can probably cross-link membrane CR3, induced superoxide bursts comparable to a $1-2 \mathrm{mg} / \mathrm{ml}$ suspension of particulate yeast $\beta$-glucan (10-20 nmol of cytochrome $C$ reduced by $2.5 \times 10^{6}$ neutrophils in $30 \mathrm{~min}$ ).

Activation of neutrophils with a variety of agents (e.g., PMA, LPS, C5a, fMLP, IL-8, TNF $\alpha$ ) results in a rapid increase in membrane expression of CR3 (52-55). Unexpectedly, treatment of neutrophils with $2 \mu \mathrm{g} / \mathrm{ml}$ of SZP, an optimal concentration for saturating and priming CR3, did not stimulate increased CR3 expression (Fig. 10), nor did such SZP priming potentiate the increased CR3 expression stimulated by $100 \mathrm{ng} /$ $\mathrm{ml}$ of LPS (not shown). Notably, SZP resembled both PMA (56) and LPS (57) in inducing the CD11b I-domain activation epitope defined by $\mathrm{mAb}$ CBRM1/5. SZP induced a higher and more sustained level of this activation epitope than did either LPS or PMA (Fig. 10), and this was not enhanced by addition of LPS to the SZP (not shown). Although levels of CBRM1/5 epitope expression comparable to those induced by SZP could be induced by higher concentrations of PMA (e.g., $1 \mu \mathrm{g} / \mathrm{ml}$ ), this frequently resulted in homotypic aggregation that prevented analysis by flow cytometry (not shown). Induction of the CBRM1/5 epitope by SZP was inhibited completely in medium containing EDTA, despite the fact that the lectin site of CR3 is divalent cation-independent and EDTA has no effect on neutrophil CR3-dependent staining by SZP-FITC or $\beta$-glucan-FITC (16). Induction of the CBRM1/5 epitope by SZP required only $1.0 \mathrm{mM} \mathrm{Mg}^{2+}$. No induction occurred with medium containing $1.0 \mathrm{mM} \mathrm{Ca}^{2+}$, and the induction with a mixture of $1.0 \mathrm{mM}$ each of $\mathrm{Ca}^{2+}$ and $\mathrm{Mg}^{2+}$ was the same as that stimulated in buffer containing $1.0 \mathrm{mM} \mathrm{Mg}{ }^{2+}$ alone (not shown). As reported for LPS induction of the CBRM1/5 epitope (57), SZP stimulation of the CBRM1/5 epitope was blocked by a brief treatment of the neutrophils with a PTK inhibitor (genistein). SZP also differed markedly from LPS and PMA in failing to induce the $\mathrm{mAb} 24$ reporter epitope representing the high affinity ICAM-1-binding state (58). The levels of $\mathrm{mAb} 24$ epitope induced by PMA, LPS, and a mixture of LPS plus SZP were equivalent to the maximum levels induced by medium containing $10 \mathrm{mM} \mathrm{Mg}{ }^{2+}$ that is known to induce this epitope maximally (59).

Somewhat similar findings were made when NK cell expression of CR3 and its activation epitopes were analyzed following cultivation with the same stimulating agents (Fig. 11). As expected, CD14-negative NK cells did not respond to LPS with increased CR3 expression or induction of CD11b activation epitopes. Only PMA up-regulated the expression of NK cell CR3, and no significant change in CR3 surface density was stimulated by SZP (Fig. 11) or a mixture of LPS and SZP (not shown). Previous studies of NK cells cultured in a similar manner with particulate yeast $\beta$-glucan, that is able to bind and cross-link membrane CR3, had shown up-regulation of CR3 expression (60). As with neutrophils, SZP priming of NK cell CR3 stimulated expression of the CBRM1/5 activation epitope. However, the level of expression was somewhat lower than that induced by PMA. Unlike neutrophils, NK cells did exhibit some increased expression of the mAb 24 epitope with SZP priming, although it was lower than the level induced by PMA. The expression of mAb 24 epitope induced by PMA was equivalent to the maximum expression induced by medium containing $10 \mathrm{mM} \mathrm{Mg}^{2+}$ (not shown).

\section{Discussion}

This investigation showed that soluble $\beta$-glucan polysaccharides similar to ones in current use for tumor immunotherapy functioned in generating in vitro tumoricidal activity through binding to the leukocyte $\beta_{2}$-integrin CR3. The binding of such polysaccharides to the lectin site of neutrophil or NK cell CR3 generated a novel primed state of the receptor that was capable of mediating cytotoxicity of iC3b-opsonized target cells that were otherwise resistant to CR3-dependent cytotoxicity. Polysaccharide priming of CR3 induced a magnesium- and tyrosine kinase-dependent conformational change in the $\alpha_{M}$ subunit that exposed the I-domain activation epitope defined by $\mathrm{mAb}$ CBRM $1 / 5$ but not the magnesium-dependent $\mathrm{mAb} 24$ reporter epitope that corresponds to the high affinity ICAM-1 


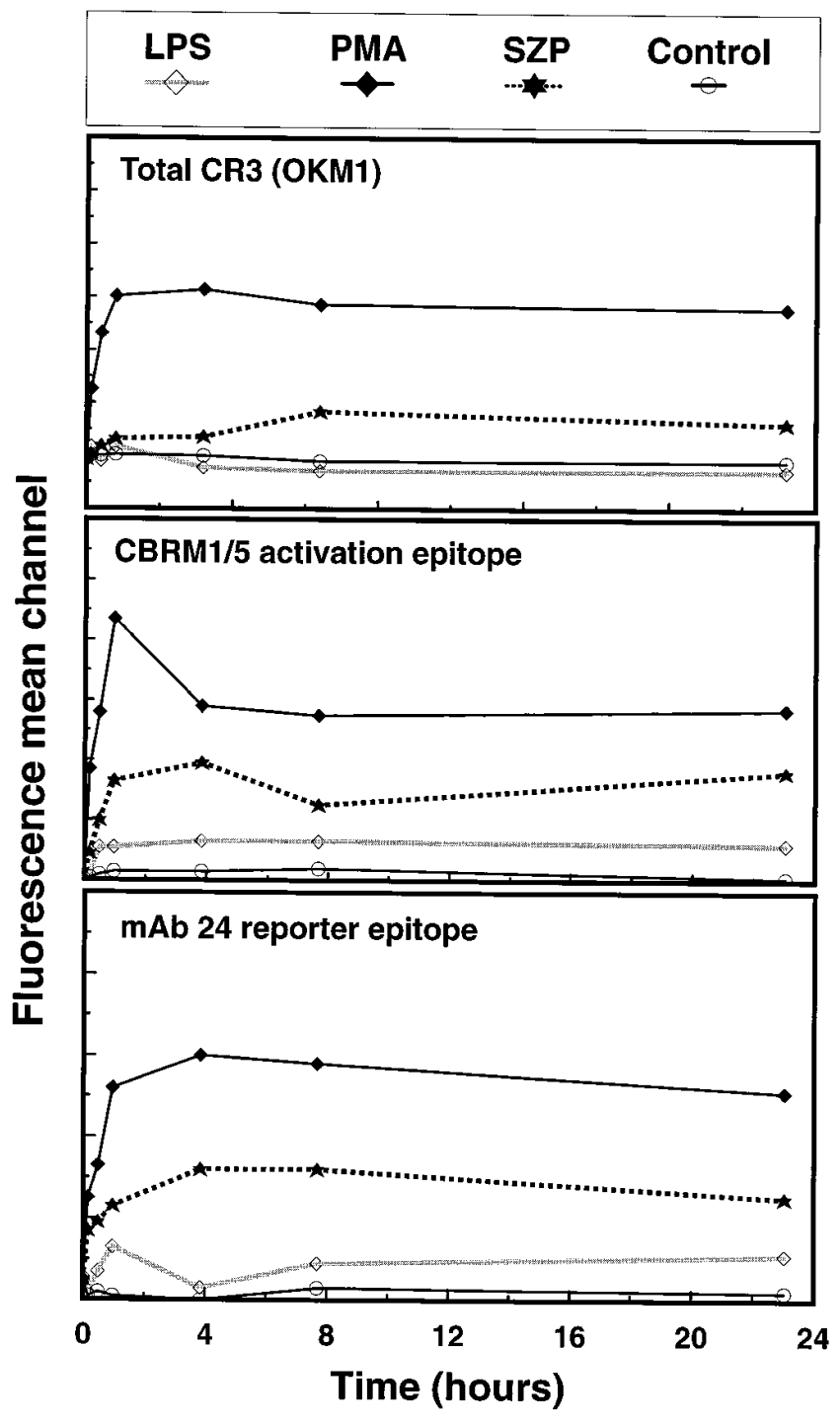

Figure 11. Up-regulation of NK cell CR3 number and activation epitopes by stimulation with SZP versus LPS or PMA. NK cells isolated under LPS-free conditions were cultured at $37^{\circ} \mathrm{C}$ for $24 \mathrm{~h}$ in RPMI/FCS medium containing $50 \mathrm{ng} / \mathrm{ml}$ of PMA, $100 \mathrm{ng} / \mathrm{ml} \mathrm{LPS}$, $2 \mu \mathrm{g} / \mathrm{ml}$ SZP (shown), or a mixture of LPS plus SZP (not shown). At the indicated time intervals, samples of the cultured NK cell suspension were washed into ice-cold medium and analyzed by flow cytometry in the same way as described for neutrophils in Fig. 10. The results shown represent the mean values from three experiments.

binding state. Polysaccharide priming of neutrophil CR3 did not activate neutrophils to express nonspecific proinflammatory functions such as enhanced substrate adhesion, homotypic aggregation, degranulation, or a respiratory burst. Specific triggering of cytotoxic functions required target cell-bound $\mathrm{iC} 3 \mathrm{~b}$, one of the specific ligands for CR3. Since many neoplastic cell types activate $\mathrm{C}$ and are coated with iC3b in vivo, tumors are naturally targeted for phagocytes and NK cells bearing polysaccharide-primed CR3.

Microbial products such as fungal $\beta$-glucans have been used as biological response modifiers to promote nonspecific mechanisms of host defense for over $100 \mathrm{yr}$. Early in this century, attempts were made to develop bacterial culture filtrates as therapeutic agents for cancer. Although some of these pro- moted tumor remission, their unpredictable nature and toxicity discouraged their continued use (61). Later, methods were found to isolate bacterial products such as BCG that had reduced toxicity while retaining host defense stimulatory properties. In 1958, zymosan were reported to induce tumoricidal activity in mice (62), and later, in 1963, the tumoricidal component of zymosan was shown to be $\beta$-glucan (63). The isolation of tumoricidal $\beta$-glucans such as lentinan and schizophyllan from edible mushrooms or fungal cultures was reported in $1969(63,64)$, and such fungal $\beta$-glucans have been used in Japan for tumor immunotherapy for the past $16 \mathrm{yr}$ (1-7). More than 500 papers, primarily from Japan, have described the structure and efficacy of tumoricidal $\beta$-glucans isolated from various fungi and bacteria.

With demonstration that CR3 served as the leukocyte receptor for particulate (28) and soluble $\beta$-glucans (16), the current study sought to define the role for CR3 in $\beta$-glucan-induced tumoricidal activity. SZP, a 10-kD mannose-rich polysaccharide that appears to have a higher affinity for CR3 than many $\beta$-glucans, was compared to both lentinan $\beta$-glucan $\left(\sim 10^{3} \mathrm{kD}\right)$ and yeast $\mathrm{MP} \beta$-glucan $(\sim 20 \mathrm{kD})$.

This investigation demonstrated that NK cell CR3 could trigger cytotoxicity independently of other receptors. Even though NK cells were known to express CR3, previous attempts to show CR3-dependent cytotoxicity had been unsuccessful. EC3bi were not lysed by NK cells $(32,33)$, NK cell cytotoxicity of K562 cells was not prevented by anti-Mac-1 (38), and $\mathrm{iC} 3 \mathrm{~b} / \mathrm{CR} 3$ interactions appeared to function primarily in enhancing recognition of tumor cells that were already weak NK cell targets $(34,65)$. Even though Di Renzo et al. (13) had demonstrated that barley $\beta$-glucan or M522 anti-CR3 could enhance NK cell cytotoxicity of K562 cells, the role played by CR3 was unclear. The current investigation showed that CR3 functioned as a $\beta$-glucan receptor to prime CR3, and then functioned secondarily in triggering NK cell cytotoxicity of targets bearing CR3 ligands. The K562 cell ligand recognized by polysaccharide-primed CR3 is unknown and is the subject of ongoing investigation. Others had previously reported that PMA-activated neutrophils could similarly mediate CR3dependent cytotoxicity of K562 cells (51).

Because of the difficulty of distinguishing CR3-dependent from CR3-independent pathways of NK cell recognition of K562 cells, the remaining investigation focused on target cells that were not recognized by normal CR3-independent mechanisms of NK cell cytotoxicity. $\beta$-glucans or SZP induced NK cells and neutrophils to lyse CR3-bound EC3bi. Such lytic activity by neutrophils was not due to LPS contamination. LPS failed to induce neutrophil CR3-dependent hemolysis, despite being able to up-regulate neutrophil CR3 membrane density and induce the expression of two $\alpha_{M}$ activation epitopes. This latter finding therefore indicates that exposure of the CBRM1/5 epitope by itself is not a marker for the primed state of CR3.

YAC-1 cells were examined because it was known that this murine tumor line was not recognized by human NK cells. Polysaccharide priming of NK cells did not induce YAC-1 cytotoxicity, indicating that YAC-1 does not express the same CR3 ligand(s) found on K562 cells. Addition of bound iC3b to the YAC-1 cells allowed avid NK cell attachment via CR3 but did not stimulate cytotoxicity. Cytotoxicity of the iC3b-YAC-1 cells required priming of CR3 with SZP or $\beta$-glucan.

CR3 plays a dual role in polysaccharide-induced cytotoxicity. First, it serves as a $\beta$-glucan/SZP receptor through its 
$\mathrm{COOH}$-terminal lectin site that acts to prime the receptor. Second, it functions as an iC3b-receptor for cytotoxic recognition of target cells via its I-domain iC3b-binding site. Thus, anti-CR3 mAbs block polysaccharide-induced cytotoxicity if added either before the polysaccharide to prevent CR3 priming or after the polysaccharide to block ligation of the primed CR3 to target cell-bound iC3b.

The ability of polysaccharides to prime CR3 for cytotoxicity was mimicked by mAb M522 that binds near to the lectin site (16). M522 is rather unique in that its $F\left(a b^{\prime}\right)_{2}$ fragment both stimulates a neutrophil respiratory burst (41) and enhances NK cell cytotoxicity of K562 cells (13). The cytotoxicity induced by M522 was blocked by OKM1, probably because OKM1 can block the ability of primed CR 3 to bind to the $\mathrm{iC} 3 \mathrm{~b}$ on target cells. Several other mAbs to $\beta_{2}$-integrin $\alpha$ or $\beta$ subunits that activate cytotoxic or adhesion functions have been reported $(24,66-69)$.

Previous studies of CR3 had suggested a role for PKCmediated phosphorylation in phagocytosis. First, CR3-mediated phagocytosis of EC3bi occurred following treatment of neutrophils or monocytes with PMA $(35,36)$. PMA had also been shown to prime neutrophil CR3 for cytotoxicity of K562 cells (51), and the current investigation demonstrated that PMA could prime NK cell CR3 for lysis of EC3bi or cytotoxicity of iC3b-YAC-1. Second, even though neutrophil phagocytosis of CR3-bound $\beta$-glucan particles did not require PMA treatment, a role for PKC-mediated phosphorylation was suggested because the ingestion of particulate $\beta$-glucan was inhibited by the PKC inhibitor staurosporine. Moreover, immunoprecipitation of CR3 from neutrophils that had ingested particulate $\beta$-glucan demonstrated staurosporine-inhibitable phosphorylation of the CR3 $\beta$-subunit (CD18) (37).

These data suggested that the binding of particulate $\beta$-glucan to the lectin site of CR3 might trigger a PKC-mediated phosphorylation event necessary for phagocytosis. However, neither PMA nor staurosporine are specific for PKC, and in particular it is known that PKC activation with PMA can lead to the activation of PTK and tyrosine phosphorylation. Moreover, others had previously reported that ligation of monocyte or macrophage CR3 with unopsonized zymosan or particulate $\beta$-glucan resulted in tyrosine phosphorylation of several cytoplasmic proteins $(70,71)$, and lyn PTK was identified in human monocytes (72). Neutrophil CR3 has also been shown to be critically involved in the tyrosine phosphorylation of paxillin (72) via $f g r$ (73). Tyrosine kinase(s) are apparently also coupled to other neutrophil signaling responses that use the lectin site of CR3 $(23,74)$ for linkage to FcyRIIIB $(75)$ or the urokinase plasminogen activator receptor (76). Accordingly, experiments were carried out to determine the potential role of PTK phosphorylation in lectin site-dependent CR3-mediated cytotoxicity.

Polysaccharide-induced CR3-dependent lysis of EC3bi by neutrophils and NK cells, as well as NK cell killing of iC3bYAC-1, were inhibited by a brief 30-min treatment with PTK inhibitors. Although baseline (CR3-independent) mechanisms of NK cell cytotoxicity of K562 cells had been reported to be blocked by a $16 \mathrm{~h}$ treatment with PTK inhibitors (50), the current investigation showed that a 30-min treatment with PTK inhibitors was selective for blockade of CR3-dependent NK cell cytotoxicity and had no effect on baseline mechanisms of K562 cell cytotoxicity.

Priming of CR3 with SZP or low mol wt MP $\beta$-glucan did not stimulate neutrophils to express any proinflammatory features characteristic of activated cells. In striking contrast to neutrophils activated with LPS, TNF $\alpha$, or PMA, polysaccharide priming of CR3 did not stimulate enhanced substrate adhesion, a superoxide burst, or homotypic aggregation. Cells remained small and round, and flow cytometry indicated no increased CR3 expression or induction of the $\mathrm{mAb} 24$ reporter epitope corresponding to the high-affinity ICAM-1-binding state. This absence of nonspecific neutrophil activation stimulated by soluble $\beta$-glucans probably accounts for their reported low level of side effects in animals and patients (77-79).

In contrast to low mol wt soluble SZP or $\beta$-glucans, high mol wt soluble $\beta$-glucans such as lentinan and particulate yeast $\beta$-glucan are large enough to cross-link membrane CR3 and activate cells. This investigation showed that lentinan could stimulate a neutrophil superoxide burst, and others have demonstrated through resonance energy transfer experiments (H.R. Petty, personal communication) the aggregation of membrane surface CR3 by either lentinan or particulate $\beta$-glucan but not by small soluble $\beta$-glucans. Although treatment of mice with soluble $\beta$-glucans enhanced the activity of splenic NK cells $(80,81)$, treatment of mice with particulate $\beta$-glucan caused a loss of all detectable NK cell function for 2 wk (82). High dose lentinan treatment of mice has also been reported to induce hemorrhagic reactions in the ears and tail (83), and mild febrile or thrombotic side effects have occasionally been noted in patients undergoing lentinan therapy (84-86).

The current data show that small soluble $\beta$-glucans or SZP can prime neutrophil or NK cell CR3 without causing nonspecific proinflammatory activation of neutrophils. Such primed CR3 can then be subsequently activated by tissue bearing fixed $\mathrm{iC} 3 \mathrm{~b}$. Normal tissue does not activate $\mathrm{C}$, but many types of tumors do activate $\mathrm{C}$ and are coated with $\mathrm{C} 3$ in situ. In patients with mammary carcinoma, an immune response to tumor Ags such as MUC-1 (87), results in antibodies that bind to tumors and activate the classical pathway of C. Such $\mathrm{C}$ activation produces little cytotoxicity because membrane regulatory proteins of the $\mathrm{C}$ system (e.g., CD46 and CD59) limit the action of the membrane attack complex. Moreover, while mammary tumors usually exhibit abundant staining for C3 (88), such tumor cell bound $\mathrm{C} 3$ does not activate macrophage or NK cell CR3. Experiments have now shown that the density of bound $\mathrm{iC} 3 \mathrm{~b} / \mathrm{C} 3 \mathrm{dg}$ on freshly isolated breast tumors is adequate for in vitro recognition and cytotoxicity by isolated NK cells bearing SZP-primed CR3 (89). In experiments with mice, SZP therapy caused regression of established mammary tumors (also bearing bound C3) without evidence of hemorrhagic reactions or other side effects (Větvička, V. and G.D. Ross, manuscript in preparation).

\section{Acknowledgments}

The authors thank Dr. Jill Buyon and Dr. Joan Merrill of New York University for performing the assays of neutrophil homotypic aggregation, and Dr. Howard Petty of Wayne State University for providing unpublished data on membrane CR3 aggregation by lentinan and particulate $\beta$-glucan obtained from resonance energy transfer experiments. The following investigators are gratefully acknowledged for donation of mAbs: Dr. Timothy A. Springer (Harvard Medical School, Boston, MA), Dr. Nancy Hogg (Imperial Cancer Research Fund, London, UK), Drs. Allison Eddy and Alfred Michael (University of Minnesota, Minneapolis, MN), Dr. Robert Todd, III (University of Michigan, Ann Arbor, MI), Prof. Dr. Ernst-Peter Rieber (In- 
stitute for Immunology, Munich University, Munich, Germany), Dr. Gerry Ritz (Dana Farber Cancer Institute, Boston MA), and Dr. Peter J. Lachmann (Medical Research Council, Cambridge, UK). They also thank Jill Johnson and the Developmental Therapeutics Program, Division of Cancer Treatment, Drug Synthesis and Chemistry Branch, National Cancer Institute, National Institutes of Health, Bethesda, MD for providing lentinan, and Dr. Julie Djeu (Moffitt Cancer Research Center, Tampa, FL) for sending YAC-1 cells.

This work was supported by USPHS Grant R01 AI27771-15, National Institutes of Health, National Institute for Allergy and Infectious Diseases, Bethesda, MD. A Wellcome Research Travel Grant from the Burroughs Wellcome Fund to G.D. Ross supported work carried out in the United Kingdom.

\section{References}

1. Taguchi, T., H. Furue, T. Kimura, T. Kondo, T. Hattori, and N. Ogawa. 1983. Clinical efficacy of lentinan on neoplastic diseases. Adv. Exp. Med. Biol. 166:181-187

2. Aoki, T. 1984. Lentinan. In Immune Modulation Agents and Their Mechanisms. R.L. Fenichel and M.A. Chirigos, editors. Marcel Dekker, Inc. New York. 63-77.

3. Taguchi, T. 1987. Clinical efficacy of lentinan on patients with stomach cancer: end point results of a four-year follow-up survey. Cancer Detect. Prev. Suppl. 1:333-349.

4. Chihara, G. 1990. Lentinan and its related polysaccharides as host defense potentiators: their application to infectious diseases and cancer. In Immunotherapeutic Prospects of Infectious Diseases. K.N. Masihi and W. Lange, editors. Springer-Verlag, Berlin. 9-18.

5. Fujimoto, T., K. Omote, M. Mai, and S. Natsuume-Sakai. 1992. Evaluation of basic procedures for adoptive immunotherapy for gastric cancer. Biotherapy. 5:153-163.

6. Oka, M., S. Yoshino, S. Hazama, K. Shimoda, and T. Suzuki. 1992. Immunological analysis and clinical effects of intraabdominal and intrapleural injection of lentinan for malignant ascites and pleural effusion. Biotherapy. 5:107112.

7. Tari, K., I. Satake, K. Nakagomi, K. Ozawa, F. Oowada, Y. Higashi, T. Negishi, T. Yamada, H. Saito, and K. Yoshida. 1994. Effect of lentinan for advanced prostate carcinoma. Acta Urol. Jpn. 40:119-123.

8. Morikawa, K., R. Takeda, M. Yamazaki, and D. Mizuno. 1985. Induction of tumoricidal activity of polymorphonuclear leukocytes by a linear $\beta-1,3-D-$ glucan and other immunomodulators in murine cells. Cancer Res. 45:1496-1501.

9. Kasai, S., S. Fujimoto, K. Nitta, H. Baba, and T. Kunimoto. 1991. Antitumor activity of polymorphonuclear leukocytes activated by a $\beta-1,3-\mathrm{D}$-glucan. $J$. Pharmacobiodyn. 14:519-525.

10. Di Luzio, N.R., R. McNamee, E. Jones, J.A. Cook, and E.O. Hoffman. 1976. The employment of glucan and glucan activated macrophages in the enhancement of host resistance to malignancies in experimental animals. In The Macrophage in Neoplasia. M.A. Fink, editor. Academic Press, New York. 181198.

11. Chen, J.-T. and K. Hasumi. 1993. Activation of peritoneal macrophages in patients with gynecological malignancies by sizofiran and recombinant interferon- $\gamma$. Biotherapy. 6:189-194.

12. Amino, M., R. Noguchi, J. Yata, J. Matsumura, R. Hirayama, O. Abe, K. Enomoto, and Y. Asato. 1983. Studies on the effect of lentinan on human immune system. II. In vivo effect on NK activity, MLR induced killer activity and PHA induced blastic response of lymphocytes in cancer patients. Jpn. J. Cancer Chemother. 10:2000-2006.

13. Di Renzo, L., E. Yefenof, and E. Klein. 1991. The function of human NK cells is enhanced by $\beta$-glucan, a ligand of CR3 (CD11b/CD18). Eur. J. Immunol. 21:1755-1758.

14. Tani, M., H. Tanimura, H. Yamaue, M. Iwahashi, T. Tsunoda, M. Tamai, K. Noguchi, and K. Arii. 1992. In vitro generation of activated natural killer cells and cytotoxic macrophages with lentinan. Eur. J. Clin. Pharmacol. 42:623-627.

15. Czop, J.K. 1986. The role of $\beta$-glucan receptors on blood and tissue leukocytes in phagocytosis and metabolic activation. Pathol. Immunopathol. Res. 5:286-296.

16. Thornton, B.P., V. Větvička, M. Pitman, R.C. Goldman, and G.D. Ross. 1996. Analysis of the sugar specificity and molecular location of the $\beta$-glucan-binding lectin site of complement receptor type 3 (CD11b/CD18). J. Immunol. 156:1235-1246.

17. Ross, G.D. 1993. Membrane complement receptors. In Clinical Aspects of Immunology. P.J. Lachmann, D.K. Peters, F.S. Rosen, and M.J. Walport, editors. Blackwell Scientific Publications, Oxford. 241-264.

18. Smith, C.W. 1993. Leukocyte-endothelial cell interactions. Semin. Hematol. 30 (Suppl.) 4:45-55.

19. Springer, T.A. 1994. Traffic signals for lymphocyte recirculation and leukocyte emigration: the multistep paradigm. Cell. 76:301-314

20. Hogg, N., and C. Berlin. 1995. Structure and function of adhesion receptors in leukocyte trafficking. Immunol. Today. 16:327-330.

21. Krych, M., J.P. Atkinson, and V.M. Holers. 1992. Complement receptors. Curr. Opin. Immunol. 4:8-13.

22. Zhou, M., R.F. Todd III, J.G.J. Van de Winkel, and H.R. Petty. 1993. Cocapping of the leukoadhesin molecules complement receptor type 3 and lymphocyte function-associated antigen-1 with $\mathrm{Fc}_{\gamma}$ receptor III on human neutrophils: possible role of lectin-like interactions. J. Immunol. 150:3030-3041.

23. Xue, W., A.L. Kindzelskii, R.F. Todd III, and H.R. Petty. 1994. Physical association of complement receptor type 3 and urokinase-type plasminogen activator receptor in neutrophil membranes. J. Immunol. 152:4630-4641.

24. Stöckl, J., O. Majdic, W.F. Pickl, A. Rosenkranz, E. Prager, E. Gschwantler, and W. Knapp. 1995. Granulocyte activation via a binding site near the C-terminal region of complement receptor type $3 \alpha$-chain (CD11b) potentially involved in intramembrane complex formation with glycosylphosphatidylinositol-anchored FcyRIIIB (CD16) molecules. J. Immunol. 154:54525463.

25. Cao, D., I.F. Mizukami, B.A. Garni-Wagner, A.L. Kindzelskii, R.F. Todd III, L.A. Boxer, and H.R. Petty. 1995. Human urokinase-type plasminogen activator primes neutrophils for superoxide anion release: possible roles of complement receptor type 3 and calcium. J. Immunol. 154:1817-1829.

26. Gyetko, M.R., R.G. Sitrin, J.A. Fuller, R.F. Todd III, H. Petty, and T.J. Standiford. 1995. Function of the urokinase receptor (CD87) in neutrophil chemotaxis. J. Leukoc. Biol. 58:533-538.

27. Zarewych, D.M., A.L. Kindzelskii, R.F. Todd III, and H.R. Petty. 1996 LPS induces CD14 association with complement receptor type 3, which is reversed by neutrophil adhesion. J. Immunol. 156:430-433.

28. Ross, G.D., J.A. Cain, B.L. Myones, S.L. Newman, and P.J. Lachmann. 1987. Specificity of membrane complement receptor type three $\left(\mathrm{CR}_{3}\right)$ for $\beta$-glucans. Complement Inflammation. 4:61-74.

29. Cain, J.A., S.L. Newman, and G.D. Ross. 1987. Role of complement receptor type three and serum opsonins in the neutrophil response to yeast. Complement Inflammation. 4:75-86.

30. Sehgal, G., K. Zhang, R.F. Todd III, L.A. Boxer, and H.R. Petty. 1993. Lectin-like inhibition of immune complex receptor-mediated stimulation of neutrophils: effects on cytosolic calcium release and superoxide production. $J$. Immunol. 150:4571-4580.

31. Krauss, J.C., H. Poo, W. Xue, L. Mayo-Bond, R.F. Todd III, and H.R. Petty. 1994. Reconstitution of antibody-dependent phagocytosis in fibroblasts expressing Fc $\gamma$ receptor IIIB and the complement receptor type 3. J. Immunol. 153:1769-1777.

32. Perlmann, P., H. Perlmann, and H.J. Müller-Eberhard. 1975. Cytolytic lymphocytic cells with complement receptor in human blood. Induction of cytolysis by IgG antibody but not by target cell-bound C3. J. Exp. Med. 141:287296.

33. Perlmann, H., P. Perlmann, R.D. Schreiber, and H.J. Müller-Eberhard. 1981. Interaction of target cell-bound C3bi and C3d with human lymphocyte receptors. Enhancement of antibody-mediated cellular cytotoxicity. J. Exp. Med. 153:1592-1603.

34. Klein, E., L. Di Renzo, and E. Yefenof. 1990. Contribution of CR3, CD11b/CD18 to cytolysis by human NK cells. Mol. Immunol. 27:1343-1347.

35. Wright, S.D., and S.C. Silverstein. 1982. Tumor-promoting phorbol esters stimulate $\mathrm{C} 3 \mathrm{~b}$ and $\mathrm{C}^{3} \mathrm{~b}^{\prime}$ receptor-mediated phagocytosis in cultured human monocytes. J. Exp. Med. 156:1149-1164.

36. Wright, S.D., and B.C. Meyer. 1986. Phorbol esters cause sequential activation and deactivation of complement receptors on polymorphonuclear leukocytes. J. Immunol. 136:1759-1764.

37. Roubey, R.A.S., G.D. Ross, J.T. Merrill, F. Walton, W. Reed, R.J. Winchester, and J.P. Buyon. 1991. Staurosporine inhibits neutrophil phagocytosis but not iC3b binding mediated by CR3 (CD11b/CD18). J. Immunol. 146:35573562 .

38. Ault, K.A., and T.A. Springer. 1981. Cross-reaction of a rat-anti-mouse phagocyte-specific monoclonal antibody (anti-Mac-1) with human monocytes and natural killer cells. J. Immunol. 126:359-364.

39. Breard, J., E.L. Reinherz, P.C. Kung, G. Goldstein, and S.F. Schlossman. 1980. A monoclonal antibody reactive with human peripheral blood monocytes. J. Immunol. 124:1943-1948.

40. Eddy, A., S.L. Newman, F. Cosio, T. LeBien, and A. Michael. 1984. The distribution of the CR3 receptor on human cells and tissue as revealed by a monoclonal antibody. Clin. Immunol. Immunopathol. 31:371-389.

41. Schulz, T.F., H. Scharfenberger, J.D. Lambris, P. Rieber, G. Riethmüller, and M.P. Dierich. 1985. Antigenic relationship between the alpha-chain of $\mathrm{C} 3$, a leukocyte-surface antigen involved in the activation of phagocytic cells, and a 50,000 MW B-cell antigen. Immunology. 54:791-800.

42. Myones, B.L., J.G. Dalzell, N. Hogg, and G.D. Ross. 1988. Neutrophil and monocyte cell surface p150,95 has iC3b-receptor $\left(\mathrm{CR}_{4}\right)$ activity resembling $\mathrm{CR}_{3}$. J. Clin. Invest. 82:640-651.

43. Bayer, E.A., and M. Wilchek. 1980. The use of the avidin-biotin complex as a tool in molecular biology. Methods Biochem. Anal. 26:1-45.

44. Shevach, E.M. 1992. Immunofluorescence and cell sorting. In Current Protocols in Immunology. J.E. Colligan, A.M. Kruisbeek, D.H. Margulies, E.M. 
Shevach, and W. Strober, editors. John Wiley and Sons, New York. 5.0.1-5.8.8 45. Timonen, T., C.W. Reynolds, J.R. Ortaldo, and R.B. Herberman. 1982. Isolation of human and rat natural killer cells. J. Immunol. Methods. 51:269277.

46. O'Rear, L.D., and G.D. Ross. 1994. Assays for membrane complement receptors. In Current Protocols in Immunology. E.M. Shevach and J. Colligan, editors. John Wiley and Sons, New York. 13.4.1-13.4.18.

47. O'Rear, L.D., and G.D. Ross. 1994. Isolation of C3 from human plasma. In Current Protocols in Immunology. E.M. Shevach and J.E. Colligan, editors. John Wiley and Sons, New York. 13.3.1-13.3.16.

48. Buyon, J.P., S.B. Abramson, M.R. Philips, S.G. Slade, G.D. Ross, G. Weissmann, and R.J. Winchester. 1988. Dissociation between increased surface expression of gp165/95 and homotypic neutrophil aggregation. J. Immunol. 140: 3156-3160.

49. Ross, G.D., V. Větvička, and B.P. Thornton. 1996. Analysis of the phagocyte membrane lectin CR3 (CD11b/CD18) using fluorescence-labeled polysaccharides and flow cytometry. In Phagocyte Functions: A Guide for Research and Clinical Evaluation. J.P. Robinson and G. Babcock, editors. John Wiley and Sons, Inc. New York. In press.

50. Einspahr, K.J., R.T. Abraham, B.A. Binstadt, Y. Uehara, and P.J. Leibson. 1991. Tyrosine phosphorylation provides an early and requisite signal for the activation of natural killer cell cytotoxic function. Proc. Natl. Acad. Sci. USA. 88:6279-6283.

51. Gavioli, R., S. Spisani, A.L. Giuliani, E. Cosulich, A. Risso, and S. Traniello. 1991. CD16 and CR3 receptors distinguish between the two mechanisms of tumour cytotoxicity in neutrophils. Br. J. Haematol. 79:170-176.

52. Berger, M., J. O'Shea, A.S. Cross, T.M. Folks, T.M. Chused, E.J. Brown, and M.M. Frank. 1984. Human neutrophils increase expression of C3bi as well as C3b receptors upon activation. J. Clin. Invest. 74:1566-1571.

53. Kishimoto, T.K., M.A. Jutila, E.L. Berg, and E.C. Butcher. 1989. Neutrophil Mac-1 and MEL-14 adhesion proteins inversely regulated by chemotactic factors. Science (Wash. DC). 245:1238-1241.

54. Neuman, E., J.W. Huleatt, and R.M. Jack. 1990. Granulocyte-macrophage colony-stimulating factor increases synthesis and expression of CR1 and CR3 by human peripheral blood neutrophils. J. Immunol. 145:3325-3332.

55. Limb, G.A., A.S. Hamblin, R.A. Wolstencroft, and D.C. Dumonde. 1991. Selective up-regulation of human granulocyte integrins and complement receptor 1 by cytokines. Immunology. 74:696-702.

56. Diamond, M.S., and T.A. Springer. 1993. A subpopulation of Mac-1 (CD11b/CD18) molecules mediates neutrophil adhesion to ICAM-1 and fibrinogen. J. Cell Biol. 120:545-556.

57. Naccache, P.H., N. Jean, N.W. Liao, J.M. Bator, S.R. McColl, and P. Kubes. 1994. Regulation of stimulated integrin surface expression in human neutrophils by tyrosine phosphorylation. Blood. 84:616-624.

58. Dransfield, I., and N. Hogg. 1989. Regulated expression of $\mathrm{Mg}^{2+}$ binding epitope on leukocyte integrin $\alpha$ subunits. EMBO (Eur. Mol. Biol. Organ.) J. 8: 3759-3765.

59. Dransfield, I., C. Cabañas, A. Craig, and N. Hogg. 1992. Divalent cation regulation of the function of the leukocyte integrin LFA-1. J. Cell Biol. 116: 219-226

60. Muto, S., V. Větvička, and G.D. Ross. 1993. CR3 (CD11b/CD18) expressed by cytotoxic $\mathrm{T}$ cells and NK cells is upregulated in a manner similar to neutrophils following stimulation with various activating agents. J. Clin. Immunol. 13:175-184

61. Nauts, H.C., W.E. Swift, and B.L. Coley. 1946. The treatment of malignant tumors by bacterial toxins as developed by the late William B. Coley, M.D., reviewed in the light of modern research. Cancer Res. 6:205-216.

62. Bradner, W.T., D.A. Clarke, and C.C. Stock. 1958. Stimulation of host defense against experimental cancer. I. Zymosan and sarcoma 180 in mice. Cancer Res. 18:347-351.

63. Diller, I.C., Z.T. Mankowski, and M.E. Fisher. 1963. The effect of yeast polysaccharides on mouse tumors. Cancer Res. 23:201-208.

64. Komatsu, N., S. Okubo, S. Kikumoto, K. Kimura, G. Saito, and S. Sakai. 1969. Host-mediated antitumor action of schizophyllan, a glucan produced by Schizophyllum commune. Gann. 60:137-144.

65. Ramos, O.F., B. Nilsson, K. Nilsson, G. Eggertsen, E. Yefenof, and E. Klein. 1989. Elevated NK-mediated lysis of Raji and Daudi cells carrying fixed iC3b fragments. Cell. Immunol. 119:459-469.

66. Robinson, M.K., D. Andrew, H. Rosen, D. Brown, S. Ortlepp, P. Stephens, and E.C. Butcher. 1992. Antibody against the Leu-CAM $\beta$-chain (CD18) promotes both LFA-1- and CR3-dependent adhesion events. J. Immunol. 148:1080-1085.

67. Pavlovic, M.D., M. Colic, N. Pejnovic, T. Tamatani, M. Miyasaka, and A. Dujic. 1994. A novel anti-rat CD18 monoclonal antibody triggers lymphocyte homotypic aggregation and granulocyte adhesion to plastic: different intra- cellular signaling pathways in resting versus activated thymocytes. Eur. J. Immunol. 24:1640-1648.

68. Ortlepp, S., P.E. Stephens, N. Hogg, C.G. Figdor, and M.K. Robinson. 1995. Antibodies that activate $\beta 2$ integrins can generate different ligand binding states. Eur. J. Immunol. 25:637-643.

69. Sugie, K., K. Nakamura, K. Teshigawara, M.S. Diamond, T.A. Springer, Y. Nakamura, W.J. Leonard, A. Uchida, and J. Yodoi. 1995. Activation of natural killer cells by the mAb YTA-1 that recognizes leukocyte function-associated antigen-1. Int Immunol. 7:763-769.

70. Sanguedolce, M.-V., C. Capo, M. Bouhamdan, P. Bongrand, C.-K. Huang, and J.-L. Mege. 1993. Zymosan-induced tyrosine phosphorylations in human monocytes: Role of protein kinase C. J. Immunol. 151:405-414.

71. Goldman, R., E. Ferber, R. Meller, and U. Zor. 1994. A role for reactive oxygen species in zymosan and $\beta$-glucan induced protein tyrosine phosphorylation and phospholipase $\mathrm{A}_{2}$ activation in murine macrophages. Biochim. Biophys. Acta Mol. Cell Res. 1222:265-276.

72. Zaffran, Y., J.C. Escallier, S. Ruta, C. Capo, and J.L. Mege. 1995. Zymosan-triggered association of tyrosine phosphoproteins and lyn kinase with cytoskeleton in human monocytes. J. Immunol. 154:3488-3497.

73. Berton, G., L. Fumagalli, C. Laudanna, and C. Sorio. 1994. $\beta 2$ integrindependent protein tyrosine phosphorylation and activation of the $F G R$ protein tyrosine kinase in human neutrophils. J. Cell Biol. 126:1111-1121.

74. Petty, H.R., and R.F. Todd III. 1993. Receptor-receptor interactions of complement receptor type 3 in neutrophil membranes. J. Leukocyte. Biol. 54: 492-494.

75. Zhou, M., D.M. Lublin, D.C. Link, and E.J. Brown. 1995. Distinct tyrosine kinase activation and Triton X-100 insolubility upon Fc $\gamma$ RII or Fc $\gamma$ RIIIB ligation in human polymorphonuclear leukocytes. Implication for immune complex activation of the respiratory burst. J. Biol. Chem. 270:13553-13560.

76. Bohuslav, J., V. Horejsí, C. Hansmann, J. Stöckl, U.H. Weidle, O. Majdic, I. Bartke, W. Knapp, and H. Stockinger. 1995. Urokinase plasminogen activator receptor, $\beta 2$-integrins, and Src-kinases within a single receptor complex of human monocytes. J. Exp. Med. 181:1381-1390.

77. Williams, D.L., E.R. Sherwood, I.W. Browder, R.B. McNamee, E.L. Jones, and N.R. Di Luzio. 1988. Pre-clinical safety evaluation of soluble glucan. Int. J. Immunopharmacol. 10:405-414.

78. Pretus, H.A., H.E. Ensley, R.B. McNamee, E.L. Jones, I.W. Browder, and D.L. Williams. 1991. Isolation, physicochemical characterization and preclinical efficacy evaluation of soluble scleroglucan. J. Pharmacol. Exp. Ther. 257:500-510.

79. Chihara, G. 1992. Recent progress in immunopharmacology and therapeutic effects of polysaccharides. Dev. Biol. Stand. 77:191-197.

80. Akimoto, M., T. Nishihira, and M. Kasai. 1986. Modulation of the antitumor effect of BRM under various nutritional or endocrine conditions. Jpn. J. Cancer Chemother. 13:1270-1276.

81. Suzuki, I., K. Hashimoto, S. Oikawa, K. Sato, M. Osawa, and T. Yadomae. 1989. Antitumor and immunomodulating activities of a $\beta$-glucan obtained from liquid-cultured Grifola frondosa. Chem. Pharm. Bull. 37:410-413.

82. Lotzová, E., and J.U. Gutterman. 1979. Effect of glucan on natural killer (NK) cells: further comparison between NK cell and bone marrow effector cell activities. J. Immunol. 123:607-611.

83. Maeda, Y.Y., M. Sakaizumi, K. Moriwaki, G. Chihara, and H. Yonekawa. 1992. Genetic control on lentinan-induced acute phase responses and vascular responses. Fol. Histochem. Cytobiol. 30:207-210.

84. Sato, Y., T. Sakai, T. Okada, Y. Sasano, T. Ando, J. Haruta, K. Kanayama, Y. Kuwahara, H. Tachino, and H. Tahara. 1990. A case of unresectable pancreatic cancer that responded to UFT chemotherapy. Gan. No. Rinsho. 36:2073-2078

85. Yoshino, S., M. Oka, S. Hazama, and T. Suzuki. 1990. Effect of intrapleural and/or intraperitoneal lentinan therapy in carcinomatous pleuritis and peritonitis. Jpn. J. Cancer Chemother. 17:1588-1591.

86. Sakaguchi, T., Y. Watahiki, and A. Kosaka. 1993. A case of breast cancer with thrombosis during treatment of lung metastasis. Jpn. J. Cancer Chemother. 20:525-528.

87. Kotera, Y., J.D. Fontenot, G. Pecher, R.S. Metzgar, and O.J. Finn. 1994 Humoral immunity against a tandem repeat epitope of human mucin MUC-1 in sera from breast, pancreatic, and colon cancer patients. Cancer Res. 54:28562860 .

88. Niculescu, F., H.G. Rus, M. Retegan, and R. Vlaicu. 1992. Persistent complement activation on tumor cells in breast cancer. Am. J. Pathol. 140:10391043.

89. Ross, G.D., B.P. Thornton, and V. Větvička. 1995. Polysaccharide priming of CR3 (CD11b/CD18) allows NK cell killing of fresh breast tumor cells. The 9th Internatl. Cong. Immunol. 95. (Abstr.) 